\title{
Adoctrinamiento turístico de los españoles en el primer franquismo: la "españolada" cinematográfica y la "diferencia" nacional asociadas a Andalucía (1940-1959)
}

The indoctrination of Spaniards on tourism during the Early Francoism: "españolada" films featuring tourists and the national "difference" linked to Andalusia (1940-1959)

María Carmen Puche-Ruiz ID, Universidad de Sevilla, España mpuche@us.es

\section{RESUMEN}

El presente trabajo se centra en el estudio de la "diferencia" nacional del primer franquismo (1940-1959), así como en su plasmación audiovisual en la "españolada" vinculada a Andalucía, como medio de adoctrinamiento para los propios españoles. Para conseguir nuestro objetivo, se analizan 45 películas con turistas en sus tramas a través del software NVivo. Los resultados apoyan con base estadística las hipótesis cualitativas, y sugieren la reiteración de cuatro tendencias en los films, desgranadas como elementos clave de la "diferencia" española asociada a Andalucía, escasamente estudiada desde el punto de vista del adoctrinamiento turístico-cinematográfico, y que revela este periodo como el más significativo del siglo veinte al respecto.

Palabras clave: turismo; siglo veinte; España; dictadura; cine.

\section{ABSTRACT}

This paper focuses on the study of the so-called Spanish national "difference", fostered by Early Francoism (1940-1959), and depicted in "españolada" films featuring tourists, as a means to indoctrinate Spaniards in favour of the tourism activity. In order to fulfil our objective, this article analyses 45 films using NVivo Software. The results, supported by statistical analysis, reinforce our qualitative hypothesis and suggest an iteration of four trends as key elements of the Francoist "difference", linked to the Andalusian synechdoche of Spain, which has been scarcely studied from the point of view of early tourism and cinematographic indoctrination, and reveals the significance of this period throughout the twentieth century.

Keywords: tourism; $20^{\text {th }}$ century; Spain; dictatorship; cinema. 


\section{INTRODUCCIÓN}

El presente trabajo se centra en el estudio de la "diferencia" nacional del primer franquismo (1940-1959), su vinculación con Andalucía, así como su plasmación audiovisual en los films con turistas del periodo, como medio de adoctrinamiento para los propios españoles. La configuración de una identidad nacional para el turismo (Afinoguénova y Martí Olivella, 2008) se convierte en este momento en materia prioritaria para los responsables del país, aspecto que se traslada a la cinematografía, con verdaderos folletos turísticos de las bellezas de España en celuloide ("Tierra y Cielo", 1941; "Ídolos", 1943). Los realizadores de la época, amparados en el proteccionismo, aíslan los elementos clave de la "diferencia" española, enunciada oficialmente por el Jefe de la Sección de Propaganda de la Dirección General del Turismo, Rafael Calleja, en la "Apología Turística de España" (1943), como una conjunción de elementos que "[...] bastaría[n] para distinguir de los demás europeos a este país por esencia diferente" (1943, p. 12): una miríada de valores autóctonos que el Régimen franquista quiere promocionar para impregnar al español de patriotismo y crear una conciencia turística nacional desde las butacas de cine. Los resultados sugieren que la "españolada" con sede en Andalucía, como género preferido y transmitido durante siglos a través de la ópera y la literatura y, más tarde, el cine (Gubern, 1977; Utrera y Delgado, 1980; Delgado, 1981), proporciona al español un espejo de tópicos amables en los que mirarse y que difundir para el turismo, como ya había hecho en regímenes anteriores (Del Rey-Reguillo, 2013; García Carrión, 2013).

Nos hallamos ante un periodo extremadamente complejo para el desarrollo de la actividad turística, por el sufrimiento de la Guerra y la durísima etapa que le siguió, a nivel interno (Bayón Mariné y Fernández Fuster, 1999; Vallejo, 2002; Pellejero, 2004), y por el avance de la II Guerra Mundial, que imposibilitaba el tráfico normal de viajeros en territorio europeo y, por tanto, la llegada a España de sus principales mercados de proximidad. En este momento de aislamiento, y pese a la evidente falta de recursos (Correyero, 2004), la Dirección General de Turismo (creada en 1939) transforma las "Rutas de Guerra" en "Rutas Nacionales" y realiza una ingente inversión en promoción turística, como paso previo a la ofensiva diplomática que llevaría al reconocimiento de España en los principales organismos internacionales a finales de la década (Moreno, 2017). De este modo, la edición de colecciones cartelísticas se suceden, y lo hace también su exposición en las películas, tanto en español, como en francés, alemán e inglés, pero siempre bajo el genérico "España”, como advierten Ramón y García en 2016 ("Bellezas de España", "Spain is beautiful and 'different'. Visit Sunny Spain"). Se trataría de un esfuerzo inexplicable, si no se contemplara la vertiente interna de esta promoción, destinada a configurar un país turístico para sus propios habitantes, que habría de recibir a los turistas de la Europa central post-conflicto (Navarro, 1943). La cultura de servicio al turista se convierte entonces en un deber patriótico, al que se llama desde las publicaciones del ramo y se fomenta desde la Federación Española de Sindicatos de Iniciativa y Turismo (Luque, 2015; ver Fotografía 1). 
Fotografía 1.: Viñeta del artículo "Cultura turística", de Eduardo Cativiela (Revista Aragón, Abril 1947, Año XXIII, № 203, p. 27)

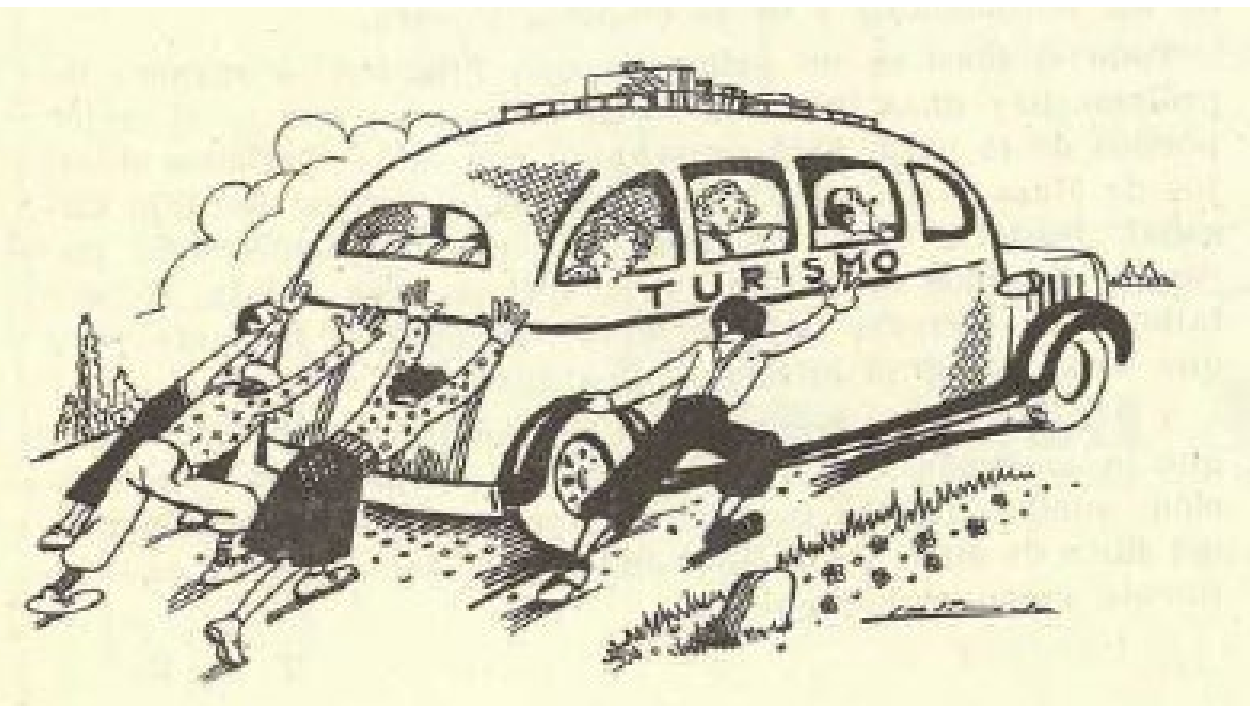

Fuente: Biblioteca Virtual de Aragón.

Se buscaba, por tanto, transmitir a los españoles "[...] lo que es el turismo y lo que puede significar como exponente representativo de una tradición, de las bellezas de un país y de las curiosas costumbres practicadas en el mismo [...]" (Cativiela, 1947, p. 27). Se pone de relieve, por tanto, que el Régimen quería asegurarse que los españoles del mañana comprendieran los valores de su patria y el verdadero poder de la propaganda turística. En ese sentido, conviene destacar que, si bien se ha estudiado profusamente la conformación de la llamada "diferencia" nacional y el adoctrinamiento franquista de los españoles a través de diferentes medios (véanse, a este respecto, los trabajos de Crumbaugh, 2002; García y Marías, 2013; De Haro, 2016; Del Río, 2016; García, 2016; Ramón y García, 2016; Domingo, 2018), se ha profundizado escasamente en el adoctrinamiento cinematográfico de raíces turísticas previo al periodo desarrollista. Porque resultaba evidente que el cine podía ejercer como método de popularización de la actividad y de la figura del turista para los españoles, en un país que pugnaba por recuperarse, tanto económica como anímicamente.

No será hasta 1953 cuando se inicie una tímida apertura, a partir de los llamados "pactos de Madrid". Según Pack (2009; 2020), en este momento, y ya bajo el Ministerio de Información y Turismo (1951), la actividad turística da el "gran salto" cuantitativo en la recepción de visitantes, lo que se refleja también en el cine y, concretamente, en la "españolada" coproducida de la década de 1950. García Carrión (2014, p. 122) advierte que este género había provocado reacciones ambivalentes en el público autóctono, porque constituía "[...] la representación estereotipada de lo español para los extranjeros [...]". Sin embargo, los elementos andaluces se encontraban en su base, "[...] asociados al simbolismo de la españolidad y [...] formaba[n] parte de la cultura de masas, algo que parecía garantizar éxito comercial". La autora mencionada opina que, si bien las "españoladas" nacionales de la década de 1920 habían representado a todas las regiones españolas, el género se había ido decantando 
progresivamente por Andalucía, hasta el punto de que en el primer franquismo la "españolada" se convierte en sinónimo de "andaluzada". Los cineastas toman buena nota de ello y reiteran en ella los rasgos definitorios de la "diferencia" nacional, contribuyendo no tanto a la difusión de una imagen concreta para el público extranjero (dado que, por ejemplo, muchas películas rodadas durante la década de 1940 ni siquiera se exhibirían en el exterior), sino al adoctrinamiento interno de millones de españoles, que soñaron con convertir España en una potencia turística.

\section{METODOLOGÍA DE ANÁLISIS}

Tras efectuar el análisis bibliográfico de la época de estudio (Cardona y Serra, 2013), se procedió a la selección y análisis de una muestra de 45 películas que exhiben los símbolos y arquetipos nacionales con una cierta carga promocional (Mestre et al., 2008), y lo hacen, además, confrontándolos a la figura del turista en su trama y su aventura en Andalucía (ver Tabla 1). Entre ellas, se pueden contabilizar tres producciones norteamericanas ("Sangre y arena", "Les girls", "Empezó con un beso"), cinco coproducciones con Latinoamérica ("Jalisco canta en Sevilla", "La guitarra de Gardel", "Una cubana en España”, "El seductor de Granada", "Para siempre, amor mío"), cuatro coproducciones con Francia ("El deseo y el amor", "La Bella de Cádiz", "Noches andaluzas", "El torero"), una coproducción con Reino Unido ("Luna de miel"), dos coproducciones con Italia ("El conde Max", "Pan, amor y Andalucía"), dos producciones Francia-Italia ("Les bijoutiers du clair de lune", "La femme et le pantin"), tres producciones netamente italianas, francesas y británicas ("Totó el matador", "Taxi, roulotte et corrida", "Tommy the toreador", respectivamente), y veinticinco películas de producción española.

Tabla 1. Muestra de 45 películas del periodo 1940-1959, obtenida tras la investigación en diversas filmotecas nacionales e internacionales

\begin{tabular}{|l|r|l|l|l|l|}
\hline Martingala & 1940 & El seductor de Granada & 1953 & El conde Max \\
\hline Sangre y arena (Rouben Mamoulian) & 1941 & La Bella de Cádiz & 1953 & Saeta del ruiseñor \\
\hline Pepe Conde & 1941 & Puebla de las mujeres & 1953 & La mujer y el pelele (Duvivier) \\
\hline Tierra y cielo & 1941 & Noches andaluzas & 1954 & Pan, amor y Andalucia \\
\hline El frente de los suspiros & 1942 & El torero & 1954 & Les bijoutiers du clair de lune \\
\hline Misterio en la marisma & 1943 & El duende de Jerez & 1954 & El Cristo de los Faroles \\
\hline La boda de Quinita Flores & 1943 & Todo es posible en Granada & 1954 & Villa Alegre \\
\hline ídolos & 1943 & Sucedió en Sevilla & 1954 & Taxi, roulotte et corrida \\
\hline Olé torero & 1948 & La Cruz de Mayo & 1955 & El hincha \\
\hline Totò el matador & 1948 & La reina mora (1955) & 1955 & Tenemos 18 años \\
\hline Jalisco canta en Sevilla & 1949 & Para siempre, amor mio & 1955 & Luna de miel \\
\hline La guitarra de Gardel & 1949 & Congreso en Sevilla & 1955 & Tommy the Toreador \\
\hline Currito de la Cruz (1949) & 1949 & Suspiros de Triana & 1955 & Empezó con un beso \\
\hline El deseo y el amor & 1951 & Good-bye Sevilla & 1955 & \\
\hline Una cubana en España & 1951 & Curra Veleta & 1956 & 1958 \\
\hline La hermana San Sulpicio (1952) & 1952 & Les qirls & 1957 \\
\hline
\end{tabular}

Elaboración propia. 
Conviene recordar que los films nacionales se encontraban sujetos a las directrices del régimen franquista por una doble vía (la censura y el proteccionismo), de modo que la exhibición de la "diferencia" nacional vinculada a Andalucía quedaba garantizada. En ese sentido, el Sindicato Nacional del Espectáculo concedía créditos a la producción, así como derechos de importación según la calificación de los films como "película de interés nacional", primera, segunda y tercera categoría. Además, otorgaba anualmente los premios anuales de cinematografía (Oficina Española de Información, 1949).

En cuanto a las coproducciones, las autoridades cinematográficas las veían como “[...] el medio más eficaz para realizar películas más caras e introducir el cine español en los mercados exteriores", una fórmula para internacionalizar la diferencia española. Porque "una coproducción pasaba a tener dos nacionalidades y en cada país era presentada según la correspondiente" (Pérez Bastías y Alonso Barahona, 1995: 68) y ofrecía la oportunidad de abrir mercados a la imagen turística de España. Existía, por tanto, un lógico interés en la proyección de estos films tanto dentro como fuera de España, y de ahí el intercambio de estereotipos reconocibles de cada país, así como de actores estrella.

Cabe destacar que el control por parte del régimen de las coproducciones era también muy estrecho, rodándose diferentes versiones conforme al país en que debían ser distribuidas. Así, conviene señalar las dobles versiones de films como "El deseo y el amor" (1951), "El sueño de Andalucía" (1950, que en Francia se tituló solamente "Andalousie") o "La Bella de Cádiz" (1953), cuyos guiones originales contienen modificaciones conforme a la censura española. En cuanto a las producciones extranjeras rodadas en España, aunque no se encontraban sujetas a los condicionantes del régimen, procuraban mostrar una visión del país coincidente con la "diferencia" nacional que propugnaba el franquismo, heredera de la visión romántica de Andalucía, incluso cuando su acción partía de Madrid (“Luna de miel”, "Empezó con un beso").

El estudio de los materiales recopilados (pertenecientes al archivo personal del autor y/o obtenidos durante investigaciones efectuadas en la Cinémathèque Française, así como en las bases de datos de Filmoteca Española y Filmoteca de Andalucía), se ha basado en el análisis sistemático de films, fotografías y textos en el que el "objeto" se convierte en "sujeto", como proponen Cipriani y Del Re (2012), tomando el objeto audiovisual como testimonio de la época en que fue rodado, un producto cultural que, en este caso, responde a las características de la industria cinematográfica de la época (proteccionismo estatal, censura cinematográfica y doblaje obligatorio de films, potenciación de las coproducciones con control de argumentos y motivos, etc.). 
Figura 1. Proceso de visionado y codificación de escenas a través de NVivo software

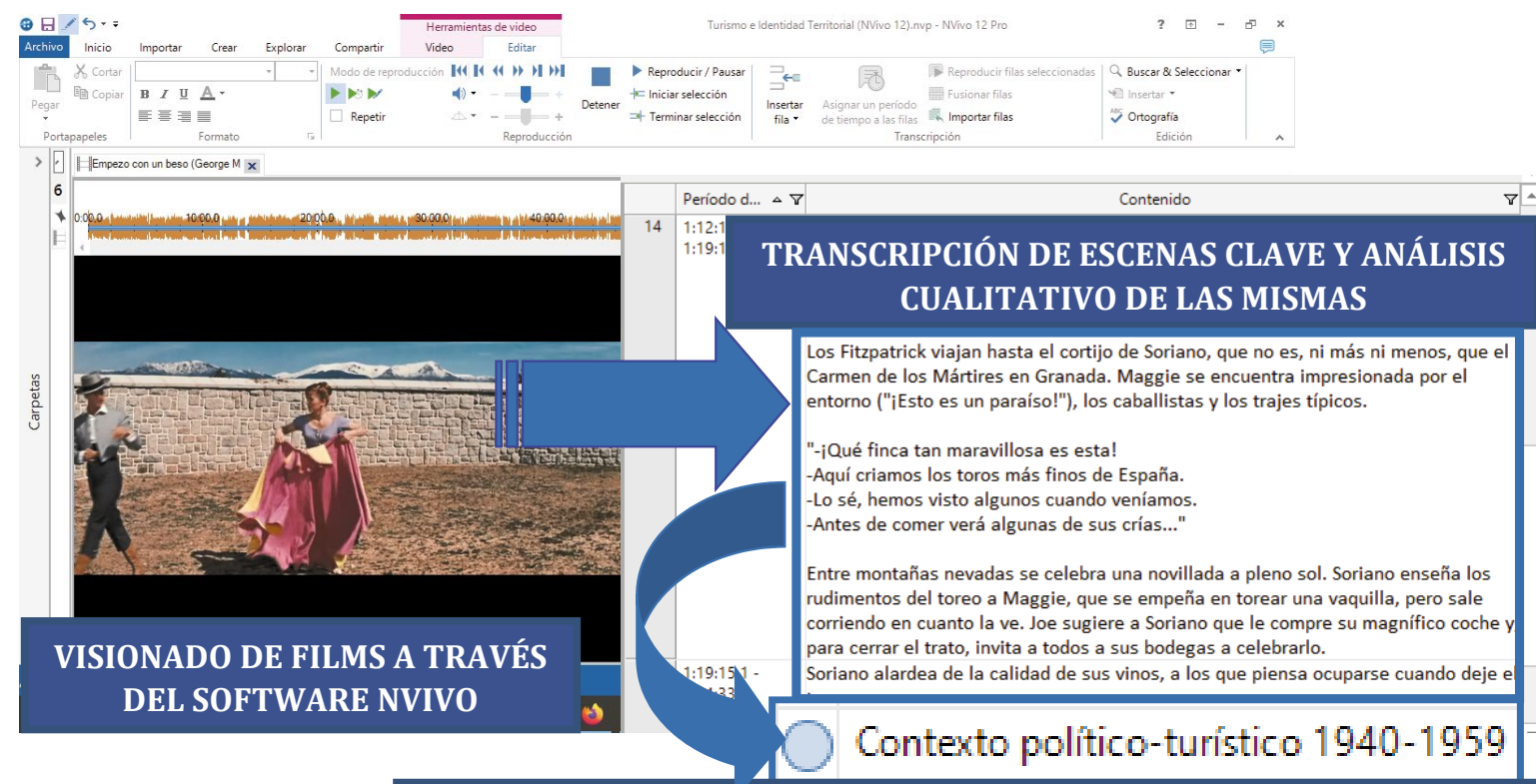

INCLUSIÓN DE LAS ESCENAS EN LA CATEGORÍA “CONTEXTO POLÍTICOTURÍSTICO (1940-1959)" Y CUANTIFICACIÓN DE LAS MISMAS

Elaboración propia.

Para llevar a cabo este trabajo, se ha establecido la categoría de análisis "Contexto político-turístico 1940-1959", en la que se han filtrado escenas, segmentos de fotografía y textos correspondientes a los films, que muestran cómo se reflejó la política nacional en el desenvolvimiento de la actividad turística durante ese periodo en Andalucía. El método utilizado, de carácter mixto y apoyado en el software NVivo, ha permitido obtener resultados de investigación de calidad, que proporcionan tanto el soporte cuantitativo para sustentar las hipótesis de investigación (número de referencias incluidas por el investigador en la categoría “Contexto político-turístico 1940-1959"), como el cualitativo (que permite analizar pormenorizadamente dichas referencias y establecer tendencias y comportamientos a través del estudio de las escenas; ver Figura 1), confiriendo al estudio un nivel de detalle y precisión imposible de alcanzar en un trabajo exclusivamente estadístico, que revela las convenciones a través de las cuales se plasmó la "diferencia" nacional del primer franquismo.

El software NVivo pertenece al grupo de herramientas CAQDAS (Computer-assisted Qualitative Data Analysis Software) que, mediante un sistema informatizado de codificación de contenidos y la comparación constante de los datos por medio de matrices de nodo, logran crear lo que se ha denominado como "teoría fundamentada". La aplicación de técnicas de análisis mixto al ámbito del turismo (Loulanski y Loulanski, 2011; Fan et al., 2017), y más específicamente, al estudio de la Historia del Turismo, puede considerarse una novedad dentro del ámbito de las Humanidades Digitales. 
Gráfica 1: Evolución del porcentaje de menciones al contexto político-turístico (periodo 19051975), en el que se ha destacado el salto cuantitativo que se produce en la etapa 1940-1959

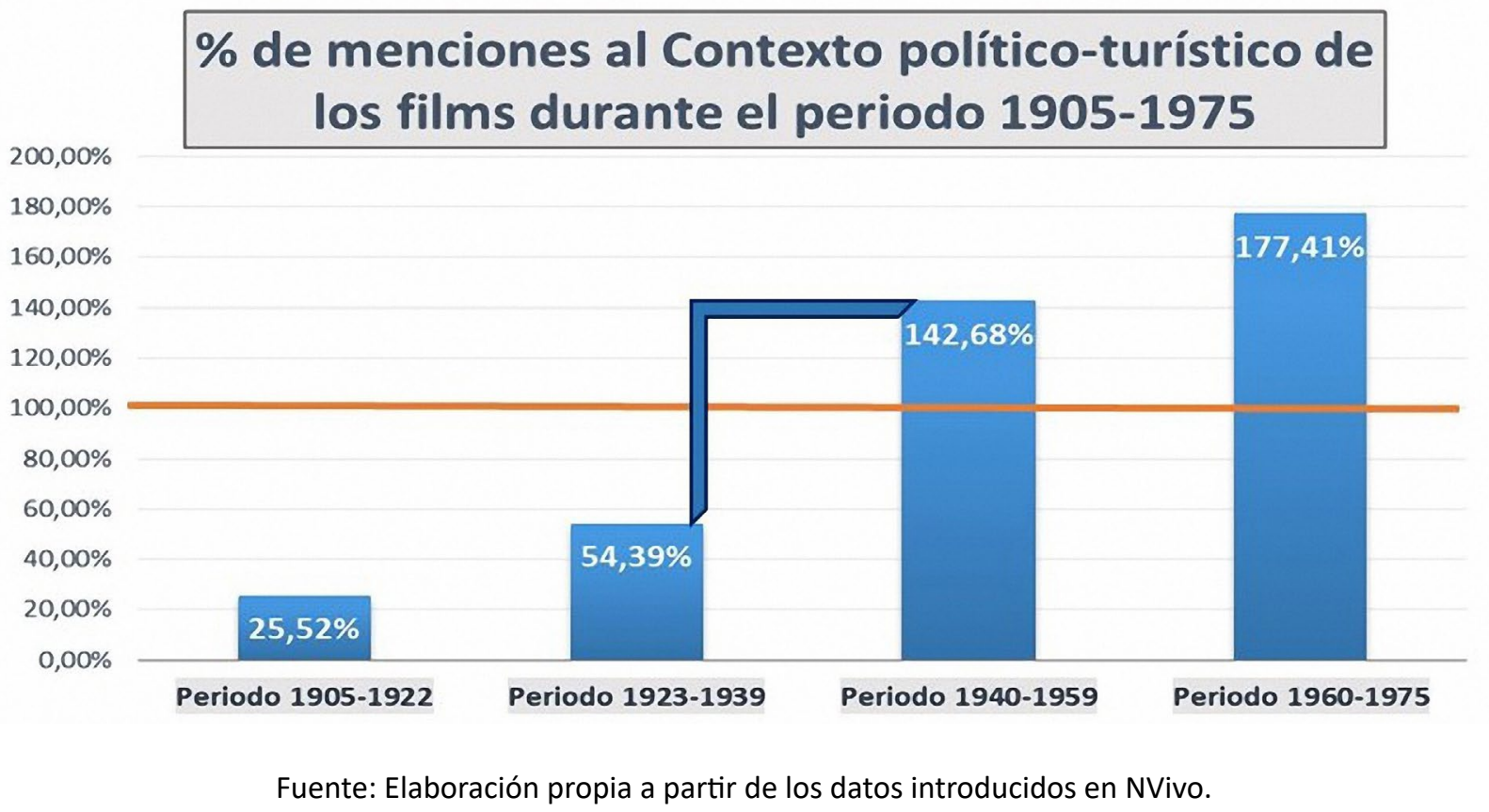

El presente trabajo deriva de un estudio más amplio de su autor, en el que se analizaron 104 películas con turistas en Andalucía, determinando cuatro etapas para el periodo 1905-1975. Este análisis previo ha permitido conocer la evolución de la actividad turística en el cine teniendo como marco sistemas políticos tan dispares como el monárquico, el republicano y el dictatorial. A través de este análisis se corrobora que el "Contexto político-turístico" del periodo 1940-1959 coincide con el "gran salto" al que alude Pack (2009). Así, de mostrar el contexto político-turístico en pantalla grande por medio de 130 referencias (periodo 19231939 , estudio realizado sobre 13 películas con turistas), se pasa a contabilizar 341 referencias en 45 películas, produciéndose un incremento del 88,28\% sobre la etapa anterior (ver Gráfica 1). La narrativa del turismo se cuela, definitivamente, en los guiones cinematográficos, a través de una eclosión de films que reflejan la actividad turística en sus tramas e introducen mensajes en favor de la actividad para los españoles.

\section{LOS CUATRO PILARES FUNDAMENTALES DE LA “DIFERENCIA" NACIONAL EN LA “ESPAÑOLADA" CON TURISTAS. CRISTALIZACIÓN DE LA SINÉCDOQUE ANDALUZA}

Las referencias al "Contexto político-turístico 1940-1959" reflejan una coincidencia casi plena de la "españolada" con turistas con el fomento de la denominada "diferencia" española por parte del Régimen franquista, aspecto que sugiere que nos hallamos ante un periodo de adoctrinamiento turístico-cinematográfico para el propio español. Este contexto turístico vinculado a la "diferencia" nacional con sede en Andalucía se muestra no solo en las 25 películas 
españolas, sino también en las 12 coproducciones con Latinoamérica, Francia, Italia y Reino Unido $y$, aunque en menor medida, en las producciones internacionales independientes.

Gráfica 2. Representatividad de las tendencias detectadas, según su porcentaje de escenas y menciones en torno a la "diferencia" española

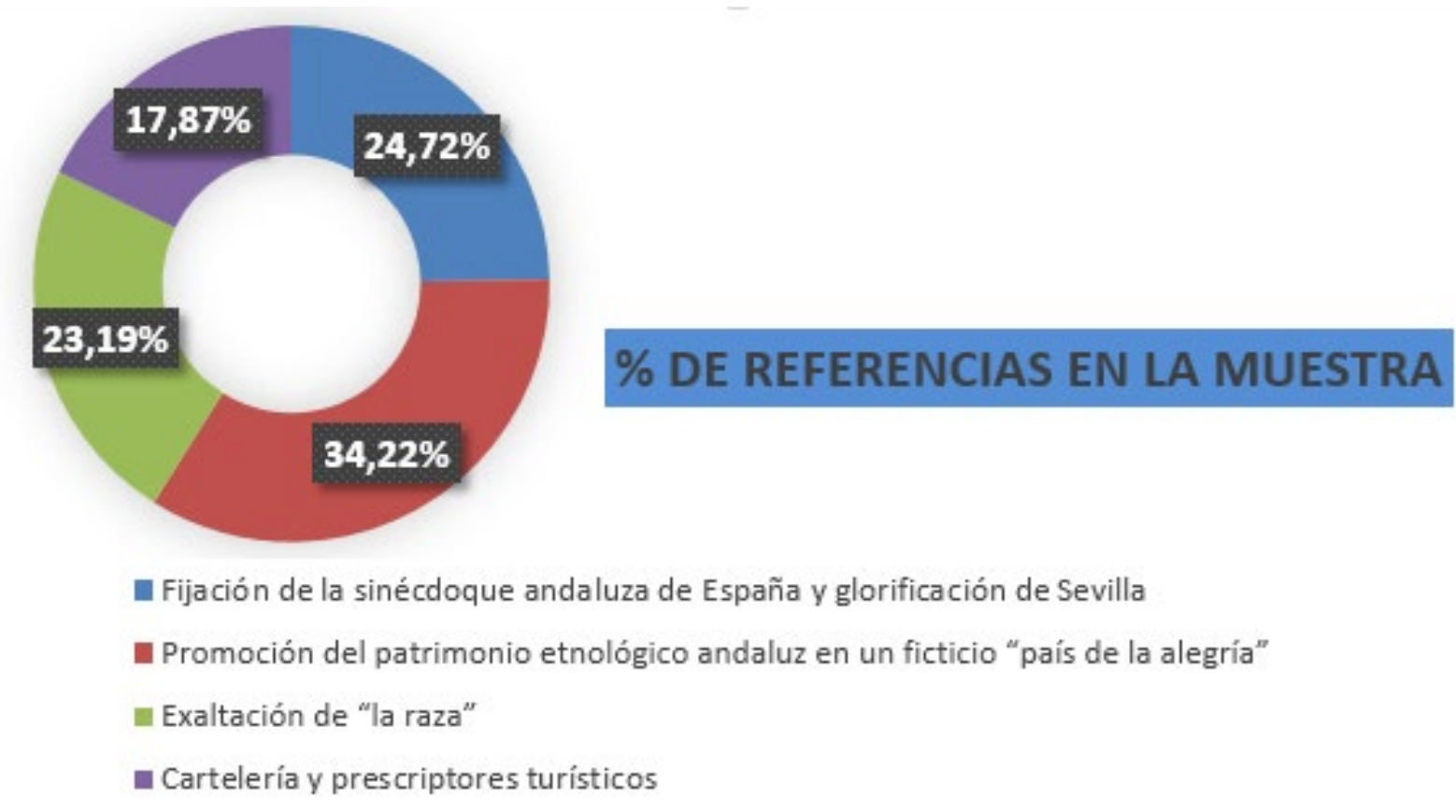

Fuente: Elaboración propia a partir de los datos introducidos en NVivo.

Así, de las 341 menciones incluidas en la categoría "Contexto político-turístico 19401959", 263 corresponden a la promoción de cuatro elementos clave de la España "diferente", que se reiteran en el cine del periodo autárquico y evolucionan durante el periodo aperturista de la década de 1950, tras la creación del Ministerio de Información y Turismo en 1951 y la firma de los Pactos de Madrid en 1953. Tal y como se muestra en la Gráfica 2, los elementos más importantes de la "diferencia" nacional en la "españolada" con turistas serán la promoción del patrimonio etnológico andaluz y la fijación de la sinécdoque andaluza del país, (transformados ambos en "marca España", y concentrando más del 50\% de las menciones al contexto turístico del periodo 1940-1959), seguidos de la exaltación de "la raza" y la inclusión en los films de promoción turística bajo la forma de carteles oficiales y prescriptores famosos.

En el epígrafe siguiente se desgranan estas cuatro tendencias, conforme a su importancia dentro del “Contexto político-turístico 1940-1959", con el fin de llevar a cabo su estudio individualizado, aislando las escenas más representativas de los 45 films que conforman la muestra objeto de estudio. En el texto se distingue entre productos destinados al consumo interno ("españoladas" nacionales) o externo ("españoladas" coproducidas) para corroborar la evolución del adoctrinamiento doméstico del espectador. 


\subsection{Promoción del patrimonio etnológico en un ficticio "país de la alegría". Fiesta, flamenco y toros}

El inicio de la autarquía coincide con la exaltación del folklore en las películas, fijando para los espectadores una España "diferente", inscrita en el eterno debate entre la seriedad castellana y el color andaluz. La "españolada" con turistas zanjará el dilema con su despliegue de patrimonio etnológico andaluz en pantalla, que concentra 90 referencias a lo largo de los films (lo que supone un 34,22\% del total; ver Gráfica 2). No en vano, Rafael Calleja afirmaba en la "Apología..." que "[l]a nota folklórica domina todo lo andaluz [...]" (1943, pp. 29-30).

Durante la década de 1940 los films con turistas todavía reflejarán la dualidad de las fiestas de primavera en Andalucía: el recogimiento de la Semana Santa frente al estaIlido de alegría de la Feria de Abril ("El frente de los suspiros", 1942; ver Fotografía 2). En la década de 1950, sin embargo, toca moderar los rasgos pasionales de las celebraciones y abordar los mecanismos modernos de promoción de España como destino turístico. Es por esto que las producciones del incipiente aperturismo se decantan rápidamente por la bulliciosa alegría de ferias y romerías frente a la barroca teatralidad de la Semana Santa, recreándose en la proyección icónica de la Feria de Abril y la Romería del Rocío ("Sucedió en Sevilla"; "La Reina Mora", "Tommy the toreador"); las Cruces de Mayo (en la película del mismo nombre, dirigida por Florián Rey en 1955), o las Fiestas de la Vendimia ("El duende de Jerez", 1954). Esta última celebración hace reflexionar con amargura al más famoso cosechero de Jerez en torno al carácter supuestamente festivo de la cultura andaluza: "Vaya, hombre, isi este es el pueblo más alegre de la tierra! España es el país de la alegría" (Segmento 2, 1:58,4-10:02,7).

La difusión del estereotipo festivo es tal que, a finales de la década, las manifestaciones folklóricas pasan a ser narradas por guías turísticos en los films, que aleccionan a los turistas al tiempo que tranquilizan al espectador. Tal es el caso de la Feria de Abril en "La femme et le pantin" (1959), que se muestra tras las ventanas panorámicas de un autobús, mientras la voz en off advierte al espectador del carácter decente de las andaluzas y de lo poco ajustado del mito francés en torno a ellas. Se impone una mirada turística sobre el folklore, con el fin de que el espectador español valorice su patrimonio etnológico no solo desde el punto de vista cultural, sino también desde el punto de vista del rédito que puede proporcionar al país, aspecto que excusa a los realizadores por su abuso del tópico. 
Fotografía 2.: Dualidad entre la Semana Santa y la Feria, como las dos fiestas más representativas de Sevilla, en un souvenir de la época

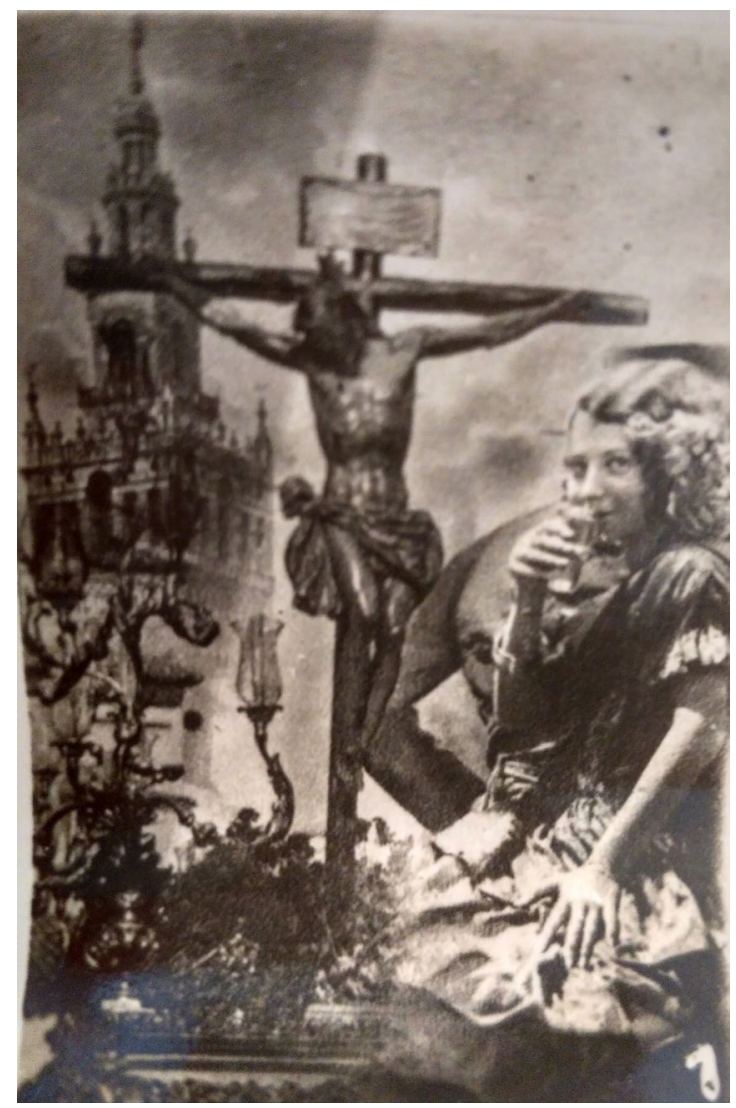

Fuente: Archivo del autor.

La promoción del folklore andaluz para el turismo conducirá, progresivamente, a la promoción de la Andalucía hedonista del vino y el flamenco. Se trata de la venta consciente, quizá por primera vez, de la oferta turística vinculada al "buen vivir" como marca-país, tanto para su público doméstico como internacional. Esta caracterización de España como destino hedonista queda reflejada en la insistencia de los realizadores por mostrar las visitas a las bodegas de Jerez (llegando a crear, incluso, una película que se convierte en una loa al vino de la tierra: "El duende de Jerez", 1954), así como por reflejar la transformación del turista tras su contacto con Andalucía y su forma de vida (ver Fotografía 3).

De este modo, las protagonistas de "Todo es posible en Granada" (1954) y "Congreso en Sevilla" (1955), perderán completamente la compostura en contacto con el vino y el baile andaluz, de la mano de cicerones locales (Francisco Rabal y Manolo Morán, respectivamente), que logran convencerlas de que su seriedad resulta un impedimento para disfrutar del modo de vida español. Los congresistas internacionales del segundo film mencionado gozarán, además, de un completo programa de festejos: "[...] fiesta campera en La Hondoná, baile de gala en el Andalucía Palace..." (Segmento 3, 9:59,6-26:37,7), el vino español en el "Hotel Cristina" o la visita a las Bodegas Pedro Domecq, a las que se agradece su colaboración en los títulos de crédito. Conviene destacar que estos films se demuestran indispensables a la hora de delimitar 
el sistema turístico de ciudades como Sevilla y Granada durante la postguerra, así como para conocer las propuestas "hedonistas" (productos, negocios, establecimientos, "night-clubs") destinadas al turismo de calidad de mediados de la década de 1950.

Fotografía 3: "Congreso en Sevilla" (1955). Desinhibición de los congresistas tras las sucesivas visitas a las bodegas del "Hotel Cristina" y los colmaos flamencos

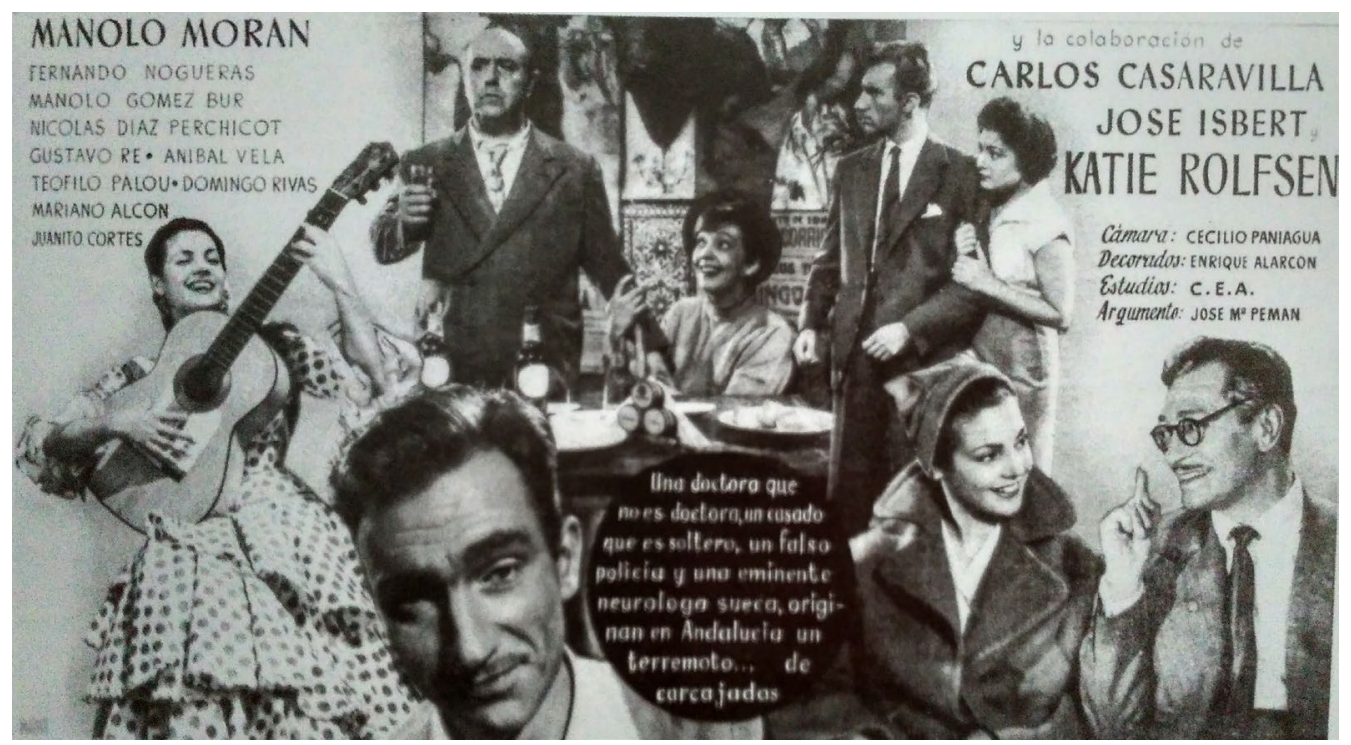

Fuente: Archivo del autor.

En cuanto a "El duende de Jerez" (1953), se trata de una exaltación de los productos vitivinícolas españoles, un film que "[...] solo se [pretende] servir desinteresadamente el tema universal de los vinos españoles". La película emplea el recurso fantástico para presentar al "duende Burguillos", que baja a la Tierra para hacer comprender a los hombres que el vino, bajo una dosis moderada, posee excelentes cualidades (Segmento 7, 25:05,3-29:20,4). Este simpático personaje se topará en Jerez con el rígido turista norteamericano Richard Byrnes, procedente de la Universidad de Massachusetts y dispuesto a desmontar la teoría hedonista creada por los cosecheros y la publicidad de la época (Segmento 2, 1:58,4-10:02,7). Sin embargo, una vez sumergido en el ambiente andaluz, entre una alegría espontánea que le es completamente ajena, se atreverá a llevar a cabo la experimentación consigo mismo, comprobando los efectos positivos del vino de la región. Una lección que "solo podía aprender en Andalucía".

Esta venta de la España hedonista se complementará con el adoctrinamiento del espectador en torno a los entresijos de la "fiesta nacional". Así, se potenciará la representación cinematográfica de los rituales vinculados con la tauromaquia en films como "El frente de los suspiros" (1942), "Ídolos" (1943) o "Misterio en la marisma" (1943). Será, sin embargo, en "Currito de la Cruz" (1948) donde esta tendencia refleje de forma clara su intencionalidad educativa, mostrando una exhibición de artes taurinas para los turistas, aspecto que se convertirá a partir de ese momento en una característica indispensable de las "españoladas". En el film mencionado, "Margaret" (turista "inglesa" interpretada por María Isbert) contemplará el 
acoso y derribo de los toros en el cortijo donde "Currito" celebra su confirmación como torero. El realizador (Luis Lucia) rueda un auténtico documental, narrado por Jorge Mistral, pieza que en absoluto hace avanzar la acción entre los personajes principales, pero que instruye al espectador en torno a las cualidades de las reses bravas (Segmento 7, 42:48,1-51:50,7).

A partir de la década de 1950, sin embargo, el turista ya no se contentará con que le expliquen, al tiempo que al espectador, los rituales taurinos, sino que se sumergirá en la experiencia de la lidia. Porque no se trataba ya tanto de introducir a los españoles en los entresijos de la cría del toro, como de comprobar cómo las estrellas cinematográficas lidiaban con ellos, certificando así el éxito turístico del país. El film "Sucedió en Sevilla" (1954) será el punto de partida para futuras coproducciones que muestran al turista extranjero "toreando" o enfrentándose a su miedo al toro. En este film, "Robert Morton" (Juanjo Menéndez), asiste a un encajonamiento y, más tarde, es invitado a torear una vaquilla. El "yankee", pese a haber sido instruido por una guía turística, no podrá evitar ser arrollado por el animal ante el regocijo de sus anfitriones (Segmento 5, 20:08,9-26:48,9).

Las estrellas nacionales pronto serán sustituidas por caras extranjeras famosas. Así, en "Noches andaluzas" (1954), la aristócrata "Dominique" (Geneviève Page) será rescatada por Mario Cabré tras ser perseguida por una manada de toros en la campiña sevillana. En "El conde Max" (1957), "Alberto" (Alberto Sordi) fotografiará de lejos los toros bravos, tratando de dominar su angustia mientras el dueño del cortijo explica los entresijos de la tienta (Segmento 4, 29:44,6-33:44,2). En “Pan, amor y Andalucía” (1958), “Antonio Carotenuto" (Vittorio De Sica) será conminado a torear solo, desmayándose de la impresión ante su amada (Segmento 7, 50:28,8-1:07:59,6). En "Les bijoutiers du clair de lune" (1958) toreará una vaquilla la mismísima Brigitte Bardot (ver Fotografía 4). En cuanto a los protagonistas de "Empezó con un beso" (1959) viajarán hasta un presunto cortijo andaluz, donde se celebra la sempiterna novillada a pleno sol para los turistas. El anfitrión enseñará los rudimentos del toreo a "Maggie" (Debbie Reynolds), que se empeñará en torear una vaquilla, pero saldrá corriendo en cuanto el animal venga hacia ella (Segmento 14, 1:12:10,9-1:19:15,2).

Se configura, así, un territorio festivo, pero carente de autenticidad, con la complicidad de los espectadores; una Andalucía de cartón piedra que, confrontada con la profundidad de Castilla, nadie parece tomarse en serio; una parodia consciente (reducida a fiesta, flamenco y toros) y a través de cuya banalidad los realizadores parecen disculparse por el abuso del folklore en pantalla. Incluso en las versiones españolas de coproducciones como "Andalousie" o "Noches andaluzas", los directores españoles se ven obligados a advertir al público español de que la región no se corresponde exactamente con la visión exagerada de los cineastas franceses. Esta tendencia hallará continuidad durante la década de 1960, si bien ya pasada por el tamiz del turismo de masas. De este modo, las fiestas camperas privadas donde brillan las estrellas internacionales en la década de 1950 se verán sustituidas por las visitas a museos taurinos y la asistencia convencional a corridas y festivales durante la década de 1960. 


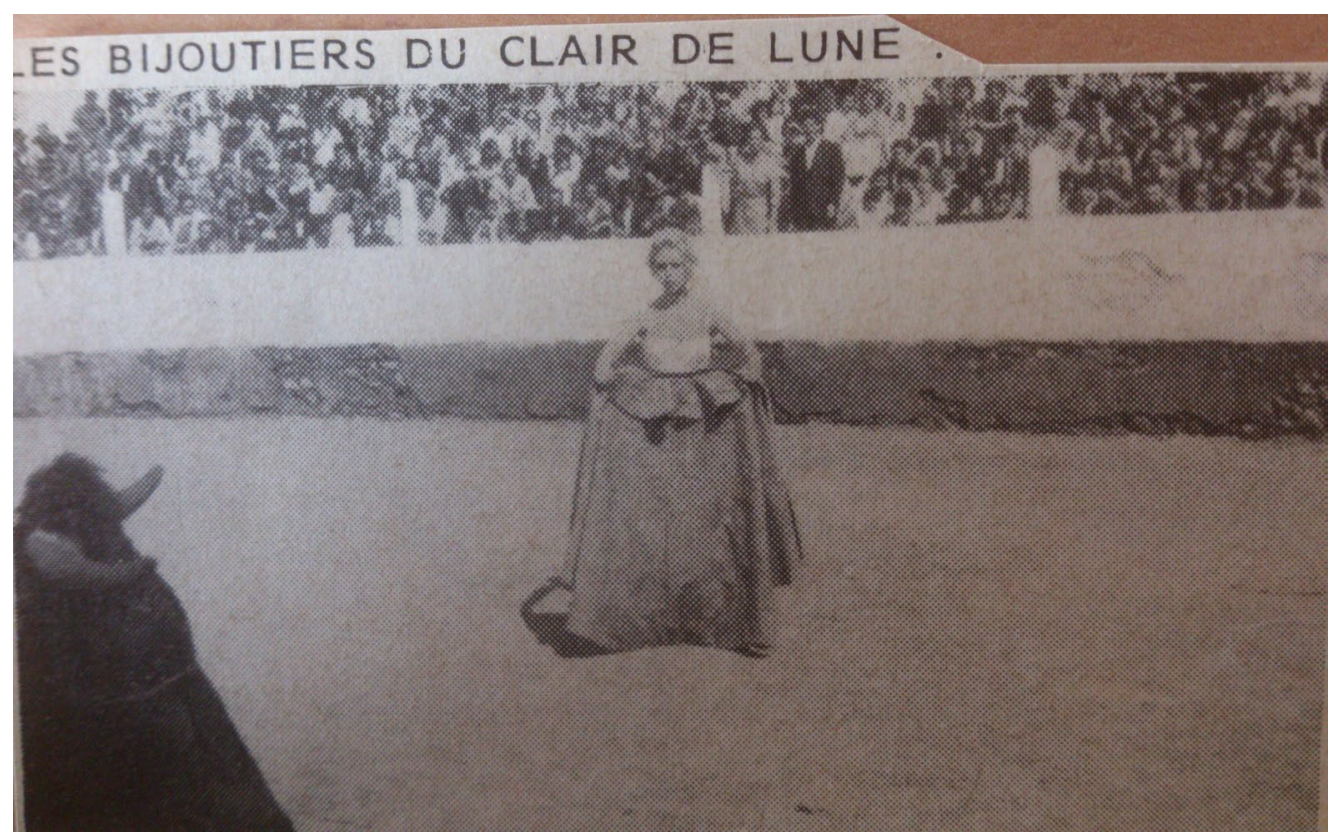

Fuente: Cinémathèque Française.

\subsection{Fijación definitiva -aunque reticente- de la sinécdoque andaluza de España. Sevilla se glorifica y su arquitectura se erige en tópico nacional}

Derivada de la tendencia anterior, la cristalización de la sinécdoque andaluza de España (con 36 menciones en escenas vinculadas al contexto turístico, lo que supone un 13,69\%) permite a los realizadores aunar los intereses domésticos e internacionales, fomentando tanto la tradición de la España periférica y de raíces rurales que defendía el franquismo -el "sur del sur", en este caso-, como la España festiva y riente, conocida dentro y fuera de nuestras fronteras, que iba a hacer las delicias de los espectadores en una España deprimida. A partir de ese momento, la loa a los motivos pintorescos y de venta típica al turista será una constante en los films: guitarras, flores, mujeres andaluzas, patios enrejados, coches de caballos, pueblos blancos... en definitiva, la estética de un mundo primigenio, hasta cierto punto rural y atrasado, que se asimila a "lo español" en el inconsciente colectivo de los espectadores (ver Fotografía 5).

Andalucía se transforma, así, en objeto de deseo, pero el turista (y los cineastas) se disculparán por preferirla frente a la sobria e imperial Castilla que le sirve de contrapunto. Ruedan conscientes de que su vistosidad, pintoresquismo y larga plasmación en las Artes ("expropiación estatal de la imagen de Andalucía" para Marchena [2007]; "andalucización" de España, según López Ontiveros [2003]), constituyen elementos infalibles de éxito en taquilla y pueden convertirse en canon turístico para los espectadores españoles. Pero también saben que un abuso del tópico puede conducir al rechazo de la propuesta, y apelan por ello a la complicidad cómica de la "españolada". El ejemplo más relevante lo encontramos ya a principios de la década de 1940, en un film ("Pepe Conde", 1941), cuyo personaje secundario, un adinerado madrileño, esconde tercamente su fascinación por Andalucía bajo un profundo desdén. Así, 
sufre numerosas calamidades (fractura de extremidades inferiores, persecución de un toro), por no aceptar complacientemente la glorificación de "lo andaluz" como representación tradicional de España. La advertencia al espectador parece clara, bajo la pátina de comicidad.

Fotografía 5. La sinécdoque andaluza de España para un director de cine norteamericano (Good-bye Sevilla, 1955)

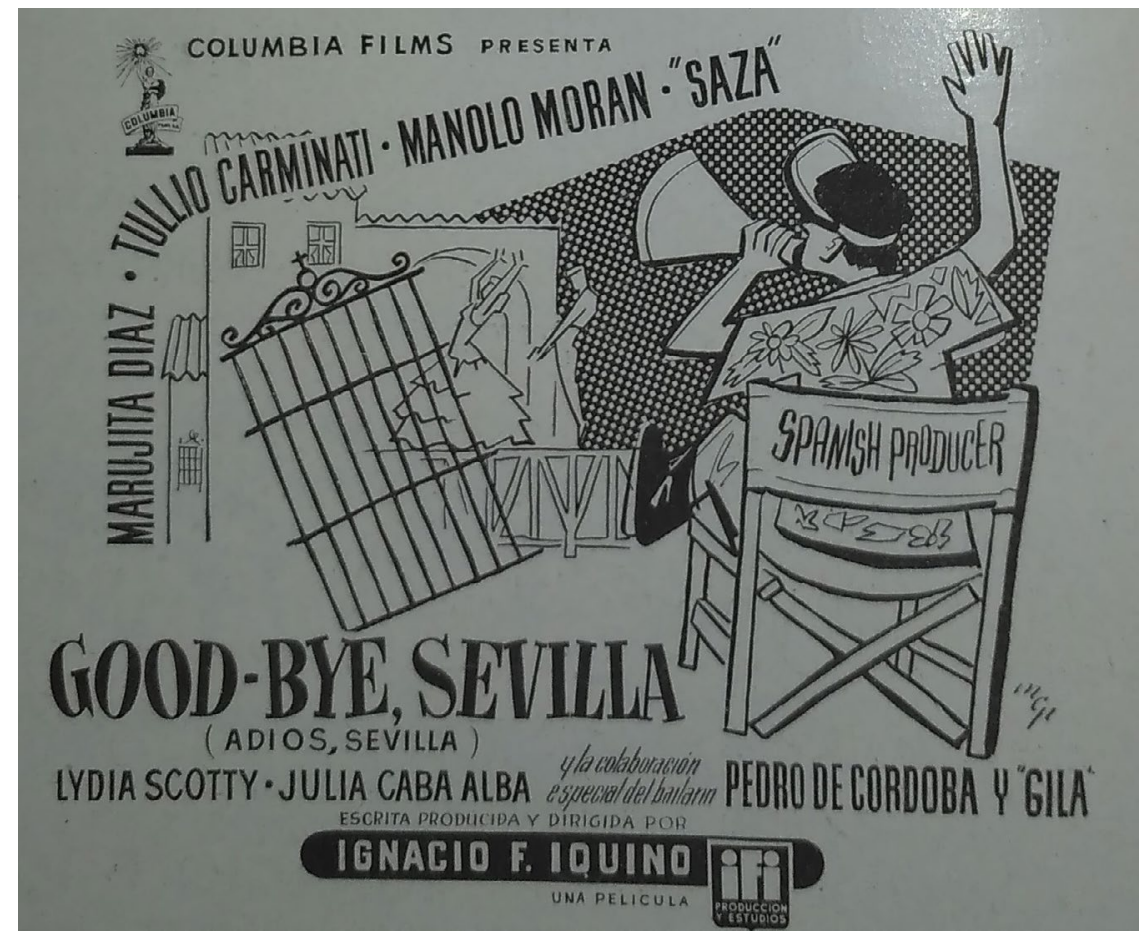

Fuente: Archivo del autor.

También los turistas internacionales se ven obligados a disfrazar su preferencia por la región andaluza bajo pretextos, como el cobro de herencias o motivos profesionales. Estos proporcionan la excusa perfecta a los cineastas para privilegiar la región y multiplicar las situaciones cómicas provocadas por estos turistas "casuales" para los que Andalucía es motivo secundario de su viaje. Se trata del caso de films como "Jalisco canta en Sevilla" (1949), "El deseo y el amor" (1951), "La Bella de Cádiz" (1953), "Noches andaluzas" (1954), "Todo es posible en Granada" (1954), "Sucedió en Sevilla" (1955), "Congreso en Sevilla" (1955), "Suspiros de Triana" (1955), "Good-bye Sevilla" (1955), "Para siempre, amor mío" (1955), "Curra Veleta" (1956) o “Pan, amor y Andalucía” (1957).

Sevilla, además, se convierte en la ciudad más representada de la muestra (con 29 menciones específicas vinculadas al contexto turístico, lo que supone un $11,03 \%$ del total). La "españolada" autárquica asume como "tradicionales" los espacios vinculados a la Exposición Iberoamericana de 1929, sintetizados por imágenes del Barrio de Santa Cruz y el Parque de María Luisa. Así, en contraste con la vorágine moderna, la arquitectura regionalista de Sevilla se convierte en tópico tradicional y recurrente en la mente de los espectadores españoles, sabedores de que "Andalucía es evocación y, dentro de esta bendita tierra, destaca Sevilla, que 
reúne todo cuanto representa una civilización que dejó honda huella en sus costumbres [...]" (Cativiela, 1945, p. 3). De esta forma, "Tierra y cielo" (1941), por ejemplo, mostrará orgullosamente la Plaza de Santa Cruz, la calle de la Pimienta con sus casas encaladas y sus enredaderas, la Plaza de Doña Elvira, la Plaza Alfaro y sus naranjos, así como las Plazas de España y América (Segmento 6, 30:55,5-41:05,9), siendo aspectos compartidos por films como "El frente de los suspiros" (Segmento 13, 42:48,1-47:59,5; Segmento 8, 21:10,3-26:53,1) o "Ídolos" (Segmento 6, 21:20,9-24:43,6).

Pero la glorificación de Sevilla como esencia de lo andaluz, de Triana como centro tradicional, y de los espacios ligados a la Exposición Iberoamericana, alcanzará su cénit en los convencionalismos de la "españolada" de la década de 1950 ("Congreso en Sevilla", "La Reina Mora", "Para siempre”, "Sucedió en Sevilla", "Good-bye Sevilla", "Suspiros de Triana”, "EI hincha", "La Cruz de Mayo"). Los realizadores utilizan la voz en off, elogiando la capital hispalense al espectador:

"Sevilla... ¿ ¿por qué estaba yo en Sevilla? Desde que llegué a Andalucía, un ansia invencible me empujaba a ver la Giralda [...], el Barrio de Santa Cruz [...], la Plaza de España en el corazón de los jardines de María Luisa... " ("La hermana San Sulpicio"; Segmento 6, 20:43,6-29:41,5).

"-[...] Lo primero que necesitamos es un escenario adecuado, lleno de sol, alegría y optimismo [...].i. Sevilla! iSomos afortunados! [...] ila ciudad más alegre y bonita de toda la Tierra!" ("Suspiros de Triana"; Segmento 2, 1:20,8-5:36,3).

Junto a los espacios de la Exposición Iberoamericana, Sevilla y la Giralda se convierten en símbolos de España, insistentemente repetidos en las coproducciones internacionales de la década de 1950 a través de imágenes ya icónicas que el espectador reconoce: panorámica de la famosa torre desde la Galería del Grutesco del Alcázar ("Una cubana en España", 1951; "El torero", 1954); desde la calle Mateos Gago ("Jalisco canta en Sevilla", 1949) o desde el Patio de Banderas (“Olé torero", 1948; "Noches andaluzas", 1954; "Good-bye Sevilla", 1955; ver Fotografía 6 ).

En cualquier caso, esta tendencia que privilegia Andalucía (y especialmente, Sevilla) como centro neurálgico del turismo para el espectador español (que concentra en su conjunto un $24,72 \%$ del total de referencias; ver Gráfica 2) se volverá más débil conforme se alcance el final de la etapa ("El conde Max", "Pan, amor y Andalucía", "La femme et le pantin") y se materialice la tensión entre los espacios patrimoniales andaluces (turismo urbano-cultural) y la Costa del Sol (turismo masivo de "sol y playa"). Porque, a finales de la década de 1950, los realizadores perciben, quizá, la sobreexplotación del escenario y comienzan a descentralizar la sinécdoque sevillana de España, desviando la atención turística hacia los otros dos vértices del triángulo patrimonial (Granada y Córdoba). El turista extranjero deja también de buscar excusas para viajar a Andalucía y manifiesta abiertamente su deseo de reconocer España en los estereotipos de una región que visita subido a un coche de lujo ("Luna de miel", "Empezó con un beso"), en un viraje de tendencia que pronto conducirá al espectador a la Costa del Sol y a la promoción desarrollista del "typical Spanish". 
Fotografía 6.: Idealización de la Giralda desde el Patio de Banderas en "Good-bye Sevilla" (1955), con la participación del bailarín Pedro de Córdoba (pressbook del film)

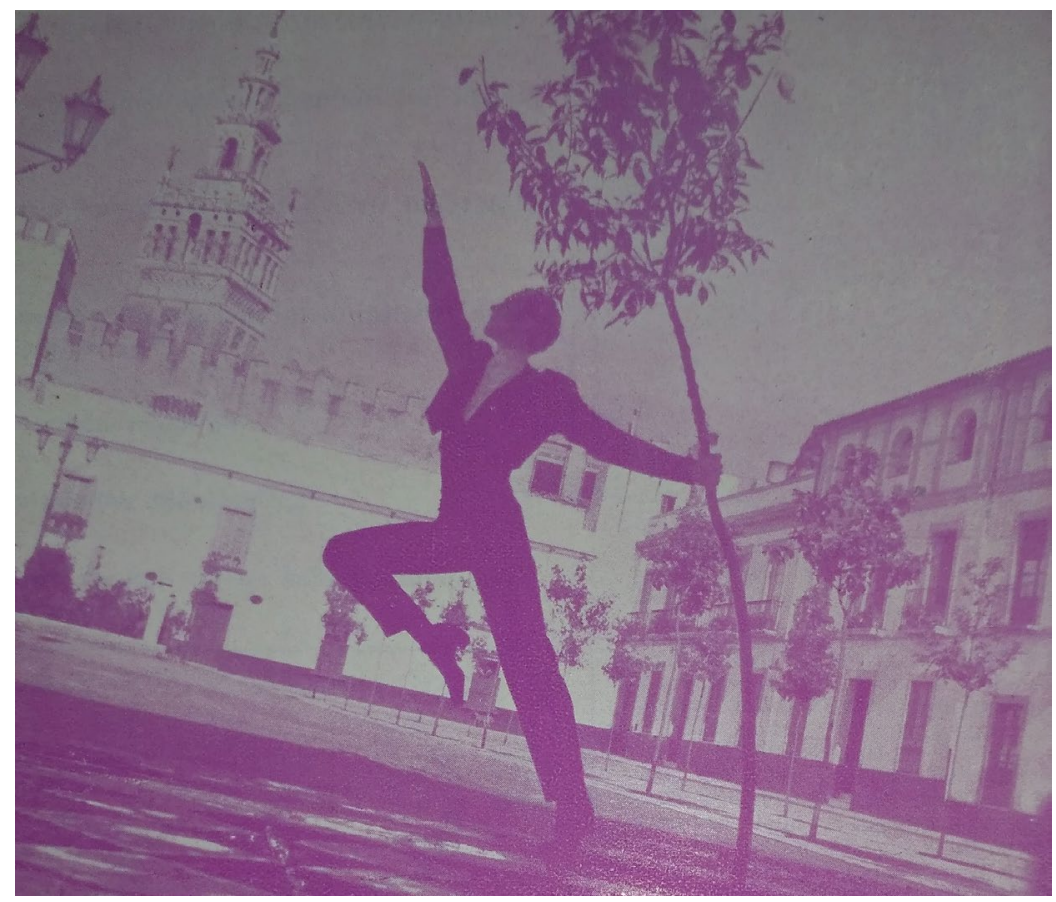

Fuente: Archivo del autor.

\subsection{Exaltación de "la raza". Hermanamiento España-Latinoamérica, visión contradictoria sobre el colectivo gitano y dicotomía Castilla-Andalucía}

La "españolada" del primer franquismo se nutrirá de los estereotipos del cine de la II República (Woods-Peiró, 2012), y privilegiará películas "fuertemente raciales" (Claver, 2012, p. 508). En el caso que nos ocupa, las menciones en torno a la exaltación de una "raza" diferente suponen un $23,19 \%$ del total (ver Gráfica 2), y se encuentran representadas por el hermanamiento entre España y Latinoamérica, la visión contradictoria del colectivo gitano y la dicotomía entre Castilla y Andalucía.

En cuanto al primero, cabe destacar que su materialización se produce a finales de la década de 1940, tras la celebración del II Congreso Cinematográfico Hispanoamericano (1948), que abre la vía al rodaje de las primeras coproducciones internacionales del franquismo. Andalucía y, sobre todo, Sevilla (como heredera de ese canto a la Raza que fue la Exposición Iberoamericana de 1929) será la sede de este hermanamiento, que aglutina hasta 24 menciones en torno al "idioma común", el "vínculo España-Iberoamérica", la visita a la "patria chica", las tradiciones de la "tierra de los abuelos", así como loas específicas a México, Argentina, Cuba y España, representando un 9,13\% del total de menciones.

La colaboración España-Latinoamérica se iniciará con films como "Jalisco canta en Sevilla" (1949), "La guitarra de Gardel" (1949), "Una cubana en España" (1951) o "El seductor de Granada" (1953), prolongándose hasta mediados de la década de 1960. Este "hermanamiento" se plasma, por ejemplo, en los títulos de crédito de la primera, que fusiona los 
elementos más significativos de México (cactus, ponchos, sombreros, desierto) con una España reducida a Andalucía (Giralda, faroles, guitarra, rejas, flores), y pone en contraste los dos estereotipos elegidos como representativos de ambos países (el "charro" y la "gitana"; ver Fotografía 7).

Fotografía 7. Los estereotipos del charro y la gitana en el programa de "Jalisco canta en Sevilla" (1949)

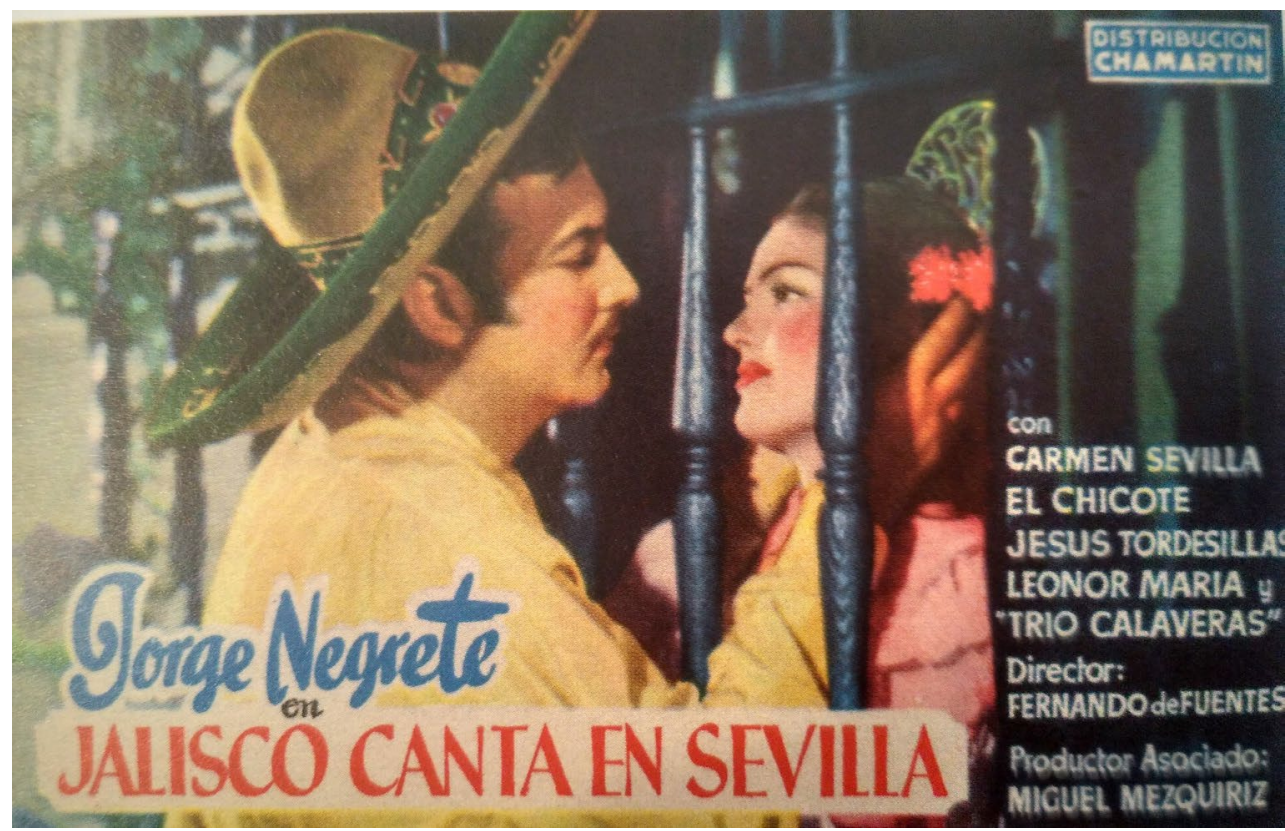

Fuente: Archivo del autor.

"Una cubana en España" (1951) se centrará, por su parte, en el enfrentamiento entre la "gitana blanca" (Maruja Díaz) y la turista cubana protagonista del film. Los dos personajes se enzarzan en un duelo para decidir quién es mejor artista de las dos, en una guerra de bongos y guitarras que acaba con una monumental pelea sobre el tablao flamenco (Segmento 3, 16:46,4-26:47,7). La trama del film se teje, así, por medio de oposiciones constantes entre los estereotipos nacionales: Mario Cabré lanzará un himno a la mujer andaluza, mientras que la belleza cubana será ensalzada por las jóvenes locales en el transcurso de una fiesta campera. El tío de la joven turista concluirá que "somos hijos de la misma madre", zanjando las discusiones entre sensibilidades diversas y apelando a la concordia de la "raza".

Otro elemento importante en la promoción de la "raza" será la representación del colectivo gitano. Los cineastas mostrarán hacia él una actitud contradictoria, basculando entre la fascinación por su cultura "diferente" y la visión paternalista-despreciativa, derivada de la nula voluntad del Régimen por fomentar su integración. Su presencia en pantalla, sin embargo, constituía un atractivo evidente para el espectador cinematográfico, familiarizado con un tópico económicamente rentable (Labanyi, 2003), reclamado también por los turistas. En ese sentido, cabe destacar que este rasgo aparece vinculado al contexto turístico de los films a través de 21 referencias (7,98\% del total). 
A principios de la década de 1940 la integración, meramente folklórica, del colectivo gitano aglutinará todos sus tópicos negativos ("Martingala" y "Pepe Conde"). Los realizadores, nuevamente, parecen disculparse por el abuso del tópico, incidiendo con mayor celo en los rasgos cómicos supuestamente atribuidos a su holgazanería e, incluso, a su tendencia a delinquir, e insistiendo en la excepcionalidad del relato, en el que los protagonistas, invariablemente, demuestran su honradez y viven el sueño de ser asimilados por la buena sociedad, tras ser víctimas de grandes prejuicios:

"-No es un gitano de camino, es un flamenco [...]. Ahora, que usted y mucha gente les tienen verdadera manía...

-Porque los conocemos.

-Bah, los gitanos tienen la gracia del sol de España. ¡Raza privilegiada! (“Martingala"; Segmento 5, 13:25,5-14:24,5).

El colectivo gitano será también representado en el cine internacional de la década de 1950, si bien su visión variará conforme se trate de películas coproducidas con Latinoamérica o con países europeos. En las primeras, su protagonismo será más evidente, dado que constituyen uno de los estereotipos confrontados, como se ha visto, suavizando sus aspectos negativos. Sin embargo, las coproducciones europeas potenciarán una imagen de atraso y nula voluntad de asimilación cultural o legal ("La Bella de Cádiz", "Noches andaluzas", "Les bijoutiers du clair de lune"). De ese modo, se percibe que los directores europeos buscaban ofrecer una imagen del gitano de camino acorde con el mito de los viajeros románticos: una suerte de bandolero errante y sin ataduras. No obstante, hay que destacar que la representación del colectivo gitano se irá debilitando conforme avance la década de 1950 y las tramas comiencen a desplazarse hacia el litoral español. Será en ese momento cuando el colectivo gitano desaparezca prácticamente de los films, o bien se suba a un tablao flamenco para diversión de los turistas del "sol y playa" español.

En cuanto a la oposición de Castilla frente al monopolio de Andalucía (y, más concretamente, al de la Sevilla cinematográfica), conviene hacer notar que los realizadores deslizan en los films 16 referencias (lo que supone un $6,08 \%$ del total) a los monumentos de las ciudades castellanas, exaltando la "raza" a través del Arte, lo que nos lleva a percibir de nuevo una fijación reticente de "lo andaluz".

A este respecto, Ramón y García perciben que Andalucía y las Castillas son las regiones más representadas en la "Apología...", creando una dicotomía que tiene su origen en el movimiento regeneracionista y que se reflejará persistentemente en el cine posterior, ya que "[...] responde bien a la concepción de la diferencia española desarrollada por Calleja y, más ampliamente, por el discurso turístico del régimen [...]" (2016, p. 404). De este modo, la España artística se utilizará para exaltar el espíritu patriótico-moral de los espectadores españoles a principios de la década de 1940. Además, esta voluntad de contraponer el arte castellano al folklore andaluz dará pie a la dicotomía publicitaria Castilla-Andalucía para los turistas de la década de 1950, que responderá a patrones promocionales vinculados con la inducción cinematográfica del turismo. 
Así, los protagonistas de "Tierra y cielo" (1941), por ejemplo, se conocen en la Galería de Miraflores durante una visita guiada. A principios de la década de 1940 convenía dar una imagen de normalidad de España, mostrando, quizá por primera vez tras la Guerra Civil, los tesoros recuperados del Museo del Prado y, concretamente, las famosas pinturas de Velázquez. El tono de las intervenciones permite descubrir que los guionistas de "Tierra y cielo" conjugan la sentimentalidad de la obra de los hermanos Álvarez Quintero con el espíritu "patriótico-moral", aspecto que también se aprecia en "El frente de los suspiros" (1942). Así, resulta clarificadora la conversación entre el protagonista masculino del film y un confidente:

"-¿Y [en el Museo del Prado] sentiste fervor por tu patria?

-Como en ninguna parte... Allí, ante prodigios y maravillas, medí su grandeza, me arrebató su gloria, sentí el santo orgullo de mi raza".

La promoción de España como "País de Arte" que exalta el sentimiento patriótico de la década de 1940, contrastará vivamente con la promoción de la Andalucía hedonista del vino y el flamenco que se venderá de forma reiterada al turista a lo largo de la década de 1950. Esta tendencia derivará en la dicotomía Castilla-Andalucía de films inductores de turismo como "Para siempre, amor mío" (1955) o "Luna de miel" (1959), que siguen parámetros promocionales similares a los empleados en películas de Hollywood como "Vacaciones en Roma" (1953) o "Locuras de verano" (1955); estrategia que retornará con fuerza durante el tardofranquismo, como resistencia de la Andalucía tradicional frente al empuje del "sol y playa".

\subsection{Cartelería y prescriptores. España se transforma en un país turístico}

Nos encontramos, quizá, ante la tendencia de adoctrinamiento para el espectador cinematográfico español más clara de la muestra, aglutinando un $17,87 \%$ de las referencias en los films analizados (ver Gráfica 2). En primer lugar, y dado que el Régimen había considerado la publicidad con fines turísticos como propaganda desde sus inicios (Orden de 9 de abril de 1941), no extraña que decidiera insertar dicha propaganda en espacios públicos, tales como casinos, estaciones de tren, salas de fiestas, recepciones de hoteles, etc., para instruir a los españoles en las bondades turísticas de su patria y excusarse, en cierto modo, por preferir Andalucía como escenario de la acción. Estos espacios, empapelados literalmente con carteles turísticos (ver Figura 2), aparecerán de forma reiterada en las películas españolas del periodo autárquico, fruto del esfuerzo promocional y cartelístico de la Dirección General del Turismo al que ya se ha aludido.

Así, la "españolada" autárquica rodada en Andalucía, que difícilmente saldría de nuestras fronteras, se llena de carteles turísticos estatales (15 menciones dentro del contexto turístico, lo que supone un $5,7 \%$ del total), como mensaje subliminal para los propios españoles. "Tierra y cielo" (1941) constituye un ejemplo relevante, por cuanto que es el primer film que muestra esta tendencia. La excusa será la huida del protagonista de París, cuya estación ferroviaria se encuentra presidida por un enorme cartel del Patronato Nacional del Turismo (década de 1930) con el genérico "Espagne" sobre la Catedral de Burgos (Segmento 2, 1:43,39:38,8; ver extremo superior izquierdo de la Figura 2). Esta tendencia se repetirá también en 
"El frente de los suspiros" (dirigida por Juan de Orduña, 1942; Segmento 5, 14:19,2-15:45,4; ver extremo superior derecho de la Figura 2) e "Ídolos" (dirigida por Florián Rey en 1943).

En esta última, la aparición de carteles turísticos llegará al paroxismo. Así, en el Segmento 5 del film (17:35,9-21:20,9), el espectador cinematográfico contempla una recepción de hotel llena de carteles y folletos (algunos editados en 1930 por el Patronato Nacional del Turismo: Alhambra de Granada ["The romance of the East with the comforts of the West"]; otros, pertenecientes a la novísima campaña "Bellezas de España": entorno rural castellano ["Spain which first attracts, then captivates and holds you"]; ver fotografía central izquierda de la Figura 2). En el Segmento 10 (39:27,4-42:22,0), el espectador asiste al baile en una sala de fiestas amenizada con el "Veraneo en las Playas de Levante" (1941) o las playas de Sitges (1940); ver fotografía central derecha de la Figura 2). Y en el Segmento 11 del film (42:22,1$43: 48,9)$ lleva incluso a cabo un tour de España a partir de carteles que anuncian las regiones más importantes ("Veraneo en las playas de Levante", "Semana Santa en Castilla" (1944); ver las fotografías inferiores de la Figura 2).

Figura 2: "Tierra y Cielo" (1941), "El frente de los suspiros" (1942) e "Ídolos" (1943). Carteles turísticos en estaciones de tren, ateneos y hoteles. Concienciación turística para un país aislado

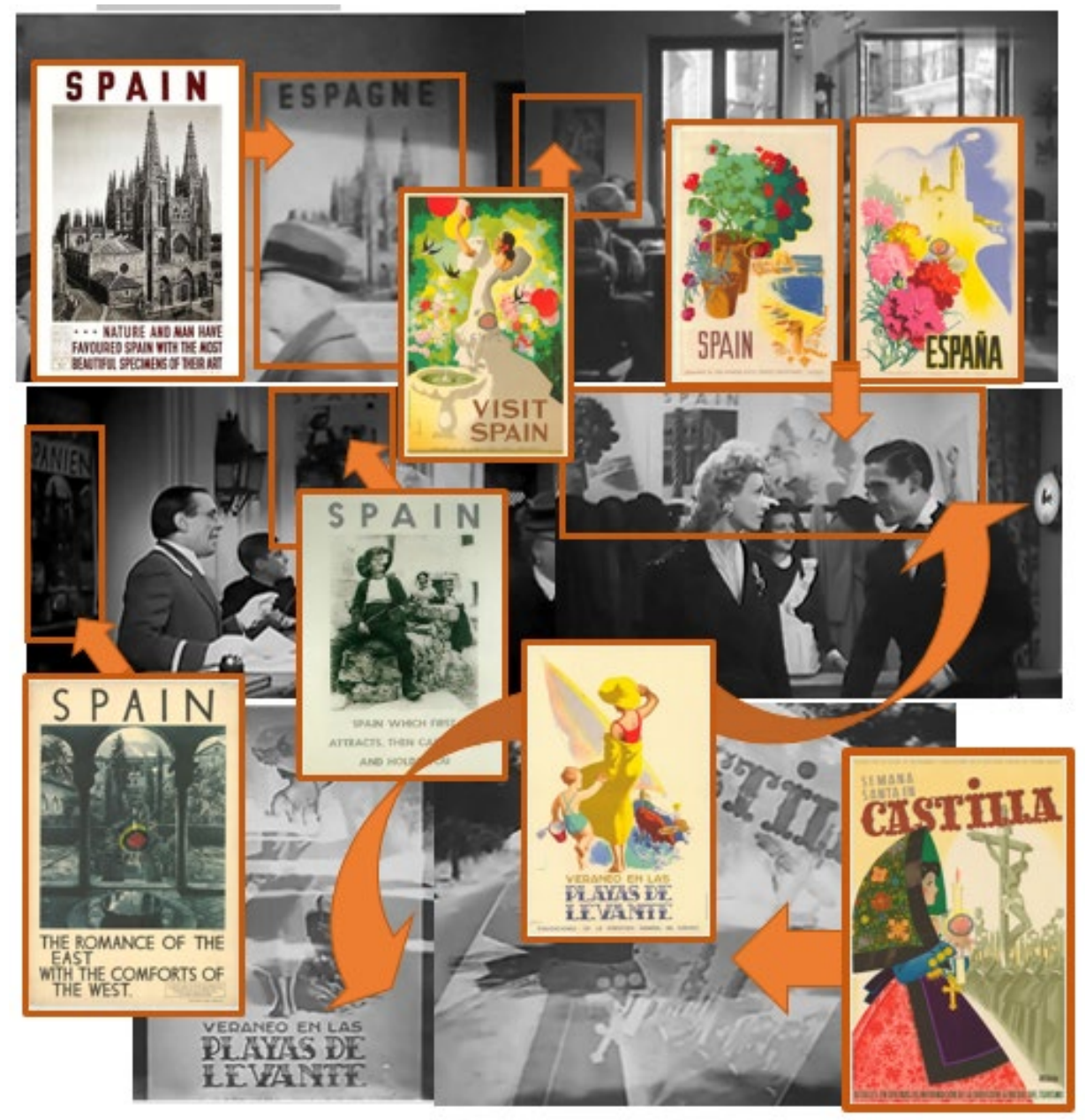

Fuente: Fotogramas de los films y Centro de Documentación Turística de España. 
Durante la década de 1950, sin embargo, esta tendencia decaerá, en favor de la que veremos a continuación. Así, se percibe la aparición puntual de carteles antiguos editados por la Dirección General del Turismo en films como "Jalisco canta en Sevilla" (recepción del "Hotel Alameda" adornada con "Playas de Levante", "Primavera en España" o "Málaga, invierno ideal"); "La hermana San Sulpicio" (estación de tren sevillana decorada con perspectivas de Lloret de Mar, Andalucía y las playas españolas); "Suspiros de Triana" y "Curra Veleta" (recepción del "Hotel Cristina" con el colorido de Sevilla bajo el genérico "España"); "Villa Alegre" (venta en la que se vislumbran los caballistas de la Feria de Sevilla), o "Taxi, roulotte et corrida" (aduana forrada con "La fiesta de toros en España", el acueducto de Segovia, Ronda o Mallorca; Segmento 3, 9:40,0-20:18,5). Este descenso en la muestra revela que, si durante la autarquía era importante mostrar a los espectadores los establecimientos turísticos oficiales empapelados de lujosos carteles para convencerles de que España podía ser un país turístico, en la década de 1950 los realizadores prefieren mostrar el relato del turismo hecho realidad, como medio de transmitir el éxito de la empresa turística nacional, vinculada cada vez más a la vertiente económica de la actividad, que anticipa los verdaderos intereses del desarrollismo turístico.

Ya en la década de 1950, en un ambiente de tímida apertura que buscaba del reconocimiento exterior, el Director General "[...] trató de intensificar los contactos con diplomáticos y hombres de negocios estadounidenses, británicos y suecos [...]" (Correyero, 2014, p. 20). A partir de ese momento, la "españolada" cinematográfica se vuelca al exterior, no solo a través de coproducciones, sino de la participación en los films de prestigiosos actores que ejercen como prescriptores del país para orgullo de los nativos (32 menciones vinculadas al contexto turístico, lo que supone un $12,17 \%$ del total). De este modo, encontramos productos diseñados para afrontar una doble vertiente: capitalizar el patriotismo turístico, mostrando cómo tratar y hacer placentera la estancia del turista en España (sobre todo, al turista norteamericano post Pactos de Madrid) y, al mismo tiempo, exhibir a las grandes estrellas del Régimen en los principales mercados cinematográficos europeos, confrontándolas con las celebridades extranjeras que disfrutan del hedonismo español. Así, en films como "El duende de Jerez", "Noches andaluzas", "Todo es posible en Granada", "Good-bye Sevilla", "Pan, amor y Andalucía" o "Luna de miel", la aventura de los famosos turistas se acompaña de la presencia de un fabuloso cuerpo de baile (del Liceo, de la compañía de Antonio "el bailarín") o de un artista invitado (Pedro de Córdoba, el propio Antonio Ruiz Soler, Dolores Vargas "la Terremoto Moreno", Pastora Imperio, Carmen Sevilla), otorgando un marchamo de calidad a las películas turísticas (ver Fotografía 8).

Más allá del ballet de "El duende de Jerez", en el que hasta los dioses loan el vino de la tierra, la extravagancia artística será un elemento común a estas manifestaciones de poderío cultural español asociado a Andalucía. Así, por ejemplo, durante el largo sueño que constituye el ballet de "Todo es posible en Granada" (1954; Segmento 7, 55:53,5-1:08:54,7), y en una delirante sucesión de escenas que en sí mismas merecerían páginas de comentarios, la actriz británica Merle Oberon penetra en un mundo surrealista, donde las huríes de Boabdil bailan con obreros norteamericanos un ritmo de jazz y twist que se exhibió en el Festival de Cannes, y donde Antonio "el bailarín", saludado como un héroe, se sumerge en las calles de Nueva York, vuela en un avión de juguete de la TWA e, incluso, se encuentra al "Tío Sam" que viaja a lomos de una modernísima aspiradora. 
Fotografía 8. "Pan, amor y Andalucía” (1958). Carmen Sevilla participando en el concurso internacional de bandas en la Plaza de España

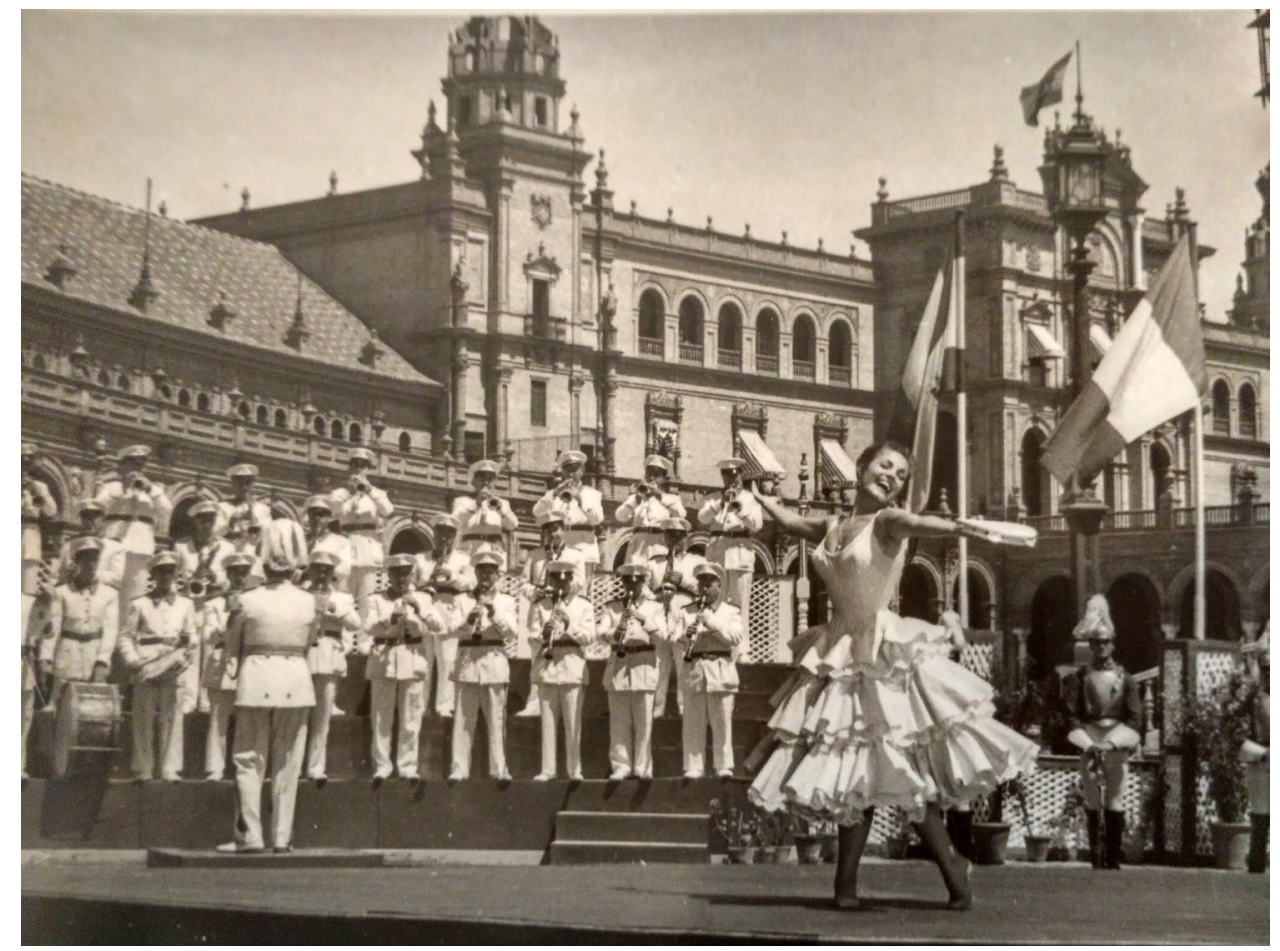

Fuente: Archivo del autor.

"Good-bye Sevilla" llevó esa extravagancia al extremo a través de "[...] la asombrosa belleza del ballet que se desarrolla en el sevillano Parque de María Luisa, en donde se pone de manifiesto la enorme habilidad de Iquino [su director] para mover grandes masas, con un sentido de la espectacularidad desconocido en nuestras pantallas" (Columbia Films, 1955, p. 1). En este fabuloso número musical se "[...] d[io] entrada [...] a toda muchacha que fuera capaz de emular con su arte el de los principales personajes de la secuencia. Se consiguieron reunir sesenta y ocho bailarinas de primer orden, pero resultaron insuficientes en el monumental escenario del Parque de María Luisa. Se requirió entonces la colaboración de cuantas artistas actuaban en salones de té y colmados, en los que tiene su sede el alma verdadera de Andalucía, lográndose así el más perfecto y numeroso conjunto que en mucho tiempo se ha visto en una película" $(1955$, p. 7). Se corrobora, de este modo, que durante la década de 1950 "[...] la propaganda de reacción -orientada en parte a los propios españoles- fue acompañada de la propaganda proactiva en el exterior para desmontar la mala imagen del régimen y ensalzar la especificidad y el atractivo de lo español [...] [combinando] la propaganda política y la más estricta promoción turística" (Vallejo, 2014: 20).

\section{CONCLUSIONES DEL ESTUDIO}

A la vista de los resultados arrojados por el estudio, se puede afirmar que la "españolada", a través de su vinculación a Andalucía y la plasmación de la figura del visitante, ejerció 
como auténtica "reeducación" turística del espectador español durante el primer franquismo, en un momento en que se produce el "gran salto" advertido por Pack (2009) hacia la conquista del turismo internacional. En ningún periodo como este la "españolada" convergió con el turismo de forma tan evidente y propagandística, incluyendo no solo la figura del turista sino la visita turística como factores docentes del espectador. En ningún periodo como este se asiste a una evolución tan clara de la "diferencia" racial para el público cinematográfico, que pasa de contemplar la presencia insistente de los gitanos en pantalla a principios de la década de 1940 (7,98\% del total de menciones) a su completa disolución en el mundo de los tablaos turísticos, o de hermanarse con los turistas iberoamericanos $(9,13 \%)$ a representar la resistencia española frente al avasallamiento "yankee" (los turistas norteamericanos de "El duende de Jerez", "Todo es posible en Granada", "Good-bye Sevilla", "Curra Veleta" o "Saeta del ruiseñor").

No en vano, en el "Contexto político-turístico" estudiado a través del software NVivo (341 referencias), hasta 263 menciones se aglutinan en torno a la promoción de una "diferencia" nacional que pronto se transformaría en "diferencia" turística. Se verifica, de este modo, la conformación de una batería de medidas destinadas a la reinvención de España como país turístico con base reticentemente andaluza (patrimonio etnológico, sinécdoque nacional, exaltación racial y comunicación publicitaria). Porque en estas cuatro tendencias subyace la excusa de los realizadores, que configuran conscientemente la región como un parque temático de la fiesta, de los toros y el sol, dando a entender a los espectadores cómplices que más allá de esa España riente existe otra España, la auténtica (el 6,08\% de menciones hacia el arte castellano). Pero sobre todo, se corrobora que la promoción de la "diferencia" en el cine estaba destinada a la conversión de los españoles en los perfectos anfitriones del turismo del centro y el norte de Europa.

Esta conversión se inicia en la década de 1940. Había que preparar a los españoles para "los turistas que vendrían" tras la II Guerra Mundial, según el Director General de Turismo; turistas que, pese a no tener la suerte de vivir en un país con el Patrimonio y la paz que disfrutaban entonces, ayudarían a los nativos a valorizar sus pueblos y ciudades. Había que educar al español medio para que pudiera convivir de forma digna con los estrafalarios turistas, y para ello nada mejor que convencerles de que España era un país de fiesta, toros y sol $(34,22 \%$ del total de menciones), como en los carteles turísticos que invadían las películas en blanco y negro $(5,7 \%)$. De ese modo, el espectador podía contemplar la aventura cinematográfica de los privilegiados turistas de "Tierra y cielo" o "Ídolos" en una Andalucía tan ficticia como los propios films. Y lo llamativo de esta sinécdoque será la conversión de la región en el símbolo riente y feliz de una España empobrecida y aislada (24,72\% del total) para un espectador que no soñaba con moverse de su ciudad o aldea, pero que contemplaba estaciones, aeropuertos y hoteles de lujo empapelados con la publicidad turística de la Dirección General del Turismo, como establecimientos fuera de la realidad de un país aspirante a convertirse en potencia turística mundial. Se concluye, por tanto, que el adoctrinamiento de la población no se limitó a documentales y noticiarios como el NO-DO, sino que traspasó la pantalla cinematográfica y los programas dobles del cine de barrio para persuadir a los ciudadanos de la "España feliz" que había que mostrar a los turistas. 
La "reeducación" del espectador cinematográfico alcanzará su cénit a mediados de la década de 1950, con el doble propósito promocional del Régimen (interior/exterior), en el que la representación de una España turística para competir en festivales cinematográficos internacionales se convierte en la excusa perfecta para imbuir a los españoles de un país turístico ficticio (12,17\% del total de menciones). El turista se sumerge en la participación experiencial del modo de vida español ("El duende de Jerez", "Todo es posible en Granada”, "Congreso en Sevilla"), sobre todo en lo concerniente al disfrute del folklore y las fiestas populares. Entre esas fiestas, sin embargo, se colaron las "juergas flamencas", las "tientas" y las "fiestas camperas", que jugaban tanto con la tradición como con los tópicos más reconocibles del país. Y España se convirtió, gracias a sus propios cineastas, en un país que había que narrar y explicar a sus ciudadanos de allende Andalucía ("Currito de la Cruz"), con el fin de que estos pudieran, un día no muy lejano, narrar y explicar a los turistas.

El adoctrinamiento de la población se verificó, por tanto, en las salas oscuras de los cines y de la mano de grandes estrellas (primero, nacionales; en la década de 1950, ya internacionales, como Merle Oberon, Geneviève Page, Katie Rolfsen, Gérard Tichy, Vittorio De Sica, Alberto Sordi, Brigitte Bardot), como forma de infundir orgullo patriótico y desprecio por una otredad ignorante aún de la España hedonista. Y poco a poco, la sociedad española fue creyendo en el sueño de Andalucía para el turismo. Lo creyeron los habitantes de Villar del Río en "Bienvenido Mr. Marshall" (Luis García Berlanga, 1953); lo creyeron los españoles que, entre risas irónicas, comprendieron que su futuro estaba "en la pandereta turística" y permitieron la suplantación de identidad que suponía venderse al turismo; lo comprendieron los realizadores españoles y extranjeros, que no pusieron en escena una Andalucía veraz, sino una película dentro de su película ("El deseo y el amor"), una reinterpretación del guion escrito de antemano ("La femme et le pantin"). Hasta el Régimen franquista claudicó y se rindió ante la evidencia de que Andalucía (la Andalucía de las películas, la Sevilla de las fiestas flamencas que "Morena clara" criticó en 1954) constituía la imagen más "vendible" del país.

La sorpresa llegó, finalmente, de la mano de los propios turistas, que también lo creyeron, y viajaron a España incluso bajo una dictadura, porque los precios eran muy bajos y, al fin y al cabo, no eran responsables de la miseria del país, sino sus salvadores (como se aprecia en la actitud de los turistas británicos de "Luna de miel"). A finales de la década de 1950, las cifras parecen dar la razón a los tecnócratas, les sobrepasan y se instalan en el imaginario cotidiano del país; imaginario que pasa, de forma brusca y festiva, de Sevilla a la costa tras un breve coqueteo con otras poblaciones (Huelva, Málaga, Almería, Córdoba, Granada), en una Andalucía sin andaluces y con las fiestas y tradiciones en formol. Poco a poco, el turismo se convierte en un gran invento, dando la razón a los sucesivos ministros de Información y Turismo y a los Directores Generales. Los espectadores, entre tanto, participaron de un momento privilegiado para detectar la intencionalidad del adoctrinamiento de la nación, no solo en torno a la visión de la "diferencia", sino también sobre la plasmación de la figura del turista en el cine, creando los rudimentos de un personaje icónico en el cine español. 


\section{BIBLIOGRAFÍA}

Afinoguénova, E. y Martí-Olivella, J. (2008). A Nation under Tourists' Eyes: Tourism and Identity Discourses in Spain. En E. Afinoguénova \& J. Marti-Olivella (Eds.), Spain is (Still) Different: Tourism and Discourse in Spanish Identity (pp. xi-xxxviii). Lanham, MD: Lexington Books.

Bayón Mariné, F. y Fernández Fuster (1999). Los orígenes. En F. Bayón Mariné, 50 años de turismo español (pp. 25-43). Madrid: Centro de Estudios Ramón Areces.

Bureau d'Information Espagnol (1949). Le Cinéma Espagnol. Madrid.

Calleja, R. (1943). Apología Turística de España. Madrid: Dirección General del Turismo.

Cativiela (octubre de 1945). Andalucía, Región Evocadora.... Páginas de Turismo Nacional, Suplemento no 3 de la Revista Aragón, Año XXI, no 196, p. 3.

Cativiela, E. (abril de 1947). Cultura turística. Revista Aragón, Año XXIII, no 203, p. 27.

Cardona, J.R. y Serra, A. (2013). Historia social del desarrollo turístico en Ibiza (décadas de 1960 y 1970). Análisis desde perspectivas historiográficas. Investigaciones Turísticas, 5 , 86-109. DOI: 10.14198/INTURI2013.5.04.

Cipriani, R. y Del Re, E.C. (2012). Imagination and Society: The Role of Visual Sociology. Cogn Process, 13 (Suppl. 2), S455-S463. DOI: 10.1007/s10339-012-0433-4.

Claver, J.M. (2012). Luces y rejas. Estereotipos andaluces en el cine costumbrista español (18961939). Sevilla: Centro de Estudios Andaluces.

Columbia Films, S.A. (1955). Good-bye Sevilla, pressbook. Madrid: Gráfica Hispanoitaliana.

Correyero, B. (2004). La administración turística española entre 1936 y 1951. El turismo al servicio de la propaganda política. Estudios Turísticos, 163-164, 55-79.

Correyero, B. (2014). La propaganda turística y la política turística española durante el franquismo... cuando el turismo no aún era de masas". I Jornadas sobre Historia del turismo. El Mediterráneo mucho más que sol y playa (1900-2010). Menorca.

Crumbaugh, J. (2002). 'Spain is Different': Touring Late-Francoist Cinema with Manolo Escobar. Hispanic Research Journal, 3(3), 261-276. DOI: 10.1179/hrj.2002.3.3.261.

De Haro, M.V. (2016). Bullfighting as television entertainment during the Franco regime. Communication and Society, 29(3), 69-85. DOI: 10.15581/003.29.3.69-85.

Del Rey-Reguillo, A. (2013). El cine como plataforma política, un sueño imposible del general Primo de Rivera. Iberic@l, 4, Dossier Monographique "Charisme et Image Politique. Figures du Monde Hispanique Contemporain", 11-24.

Del Río, I. (2016). Cultura y paisaje en la política turística del primer franquismo (1939-1956). Estudios Geográficos, LXXVII(281), 443-467. DOI: 10.3989/estgeogr.201614.

Delgado, J.-F. (1981). El Cine. Colección Cosas de Sevilla. Sevilla: Grupo Andaluz de Ediciones Repiso-Lorenzo.

Domingo, I. (2018). A diabolical plaything: empty signifiers and the construction of Francoism's long-lasting historical myth in Spain. Social Semiotics, DOI: 10.1080/10350330. 2018.1552509

Fan, D., X., F., Qiu Zhang, H., Jenkins, C.L. y Tavitiyaman, P. (2017). Tourist Typology in Social Contact: an addition to Existing Theories. Tourism Management, 60, 357-366. DOI: 10.1016/j.tourman.2016.12.021. 
García, D.B. (2016). El interés por el paisaje en la política turística española de la segunda mitad del siglo XX (1957-1978). Estudios Geográficos, 77(281), 391-414. DOI: 10.3989/ estgeogr.201612.

García, J. y Marías, D. (2013). Geographical magazines and popular geographies: The case of the Revista Geográfica Española, 1938-1977. Journal of Historical Geography, 39, 85-98. DOI: 10.1016/j.jhg.2012.06.001.

García Carrión, M. (2013). Por un cine patrio. Cultura cinematográfica y nacionalismo español (1926-1936). València: Publicacions Universitat de València.

García Carrión, M. (2014). Spain on the big screen: Regional imaginary, popular culture and national identity in the cinema of the first half of the twentieth century. Catalan Journal of Communication \& Cultural Studies, 6(1), 115-131. DOI: 10.1386/cjcs.6.1.115_1.

Gubern, R. (1977). El cine sonoro de la II República. Madrid, Barcelona: Lumen.

Labanyi, J. (2003). Lo andaluz en el cine del franquismo: los estereotipos como estrategia para manejar la contradicción. Documento de Trabajo Serie Humanidades H2004/02. Sevilla: Fundación Centro de Estudios Andaluces.

López Ontiveros, A. (2003). Geografía de Andalucía. Barcelona: Editorial Ariel.

Loulanski, T. y Loulanski, V. (2011). The Sustainable Integration of Cultural Heritage and Tourism: a Meta-Study. Journal of Sustainable Tourism, 19(7), 837-862. DOI: 10.1080/09669582.2011.553286.

Luque, M. (2015). El desarrollo del sector turístico durante la Segunda República y el Primer Franquismo: La Federación Española de Sindicatos de Iniciativa y Turismo (Tesis doctoral). Universidad de Málaga.

Marchena, M.J. (2007). La imagen geográfica de Andalucía. Sevilla: RD Editores.

Mestre, R., Del Rey-Reguillo y A., Stanishevski, K. (2008). The Image of Spain as Tourist Destination Built Through Fictional Cinema. Journal of Travel \& Tourism Marketing, 24 (2-3), 185-194. DOI: 10.1080/10548400802092718.

Moreno, A. (2017). Come to Spain! America in Spanish tourism policy (1911-1954). Journal of Tourism History, 9 (2-3), 193-204. DOI: 10.1080/1755182X.2017.1410234.

Navarro "Pyrene", V. (Noviembre de 1943). La VI Asamblea de la Federación Española de Sindicatos de Iniciativa y Turismo, Revista Aragón, "Páginas de Turismo Nacional", Año XIX, no 185 , pp. 102-108.

Pack, S. (2009). La invasión pacífica. Los turistas y la España de franco. Madrid, Turner.

Pack, S. (2020). Las múltiples caras del turismo en la Europa contemporánea. En R. Vallejo \& C. Larrinaga, Los orígenes del Turismo en España. El nacimiento de un país turístico 19001939 (pp. 43-65). Madrid: Sílex.

Pérez Bastías, L. y Alonso Barahona, F. (1995). Las mentiras sobre el cine español. Royal Books. Pellejero, C. (2004). La política turística en España. Una perspectiva histórica. En J. Aurioles Martín (Ed.), Las nuevas formas del turismo (pp. 268-284). Instituto Cajamar.

Ramón, M. y García, J. (2016). Fotografía, turismo e identidad nacional en el primer franquismo (1939-1959): Rafael Calleja y la Apología turística de España. Cuadernos de Turismo, 38, 385-410. DOI: 10.6018/turismo.38.1491.

Utrera, R. y Delgado, J.-F. (Eds.). (1980). Cine en Andalucía. Sevilla: Argantonio.

Vallejo, R. (2002). Economía e historia del turismo español del siglo XX. Historia Contemporánea, $25,203-232$. 
Vallejo, R. (2014). De país turístico rezagado a potencia turística. El turismo en la España de Franco. Documento de Trabajo de la Asociación Española de Historia Económica, no 1408.

Woods-Peiró, E. (2012). White Gypsies. Race and Stardom in Spanish Musicals. University of Minnesota Press.

\section{AGRADECIMIENTOS:}

"LAS CIUDADES ESPAÑOLAS EN LA FICCIÓN AUDIOVISUAL. REGISTRO DOCUMENTAL Y ANÁLISIS TERRITORIAL Y AUDIOVISUAL (FACES-50)" RTI2018-094100-B-100. Ministerio de Ciencia e Innovación.

“INTELIGENCIA TERRITORIAL VS. CRECIMIENTO TURÍSTICO. LA PLANIFICACIÓN Y GESTIÓN DE DESTINOS ANTE EL NUEVO CICLO EXPANSIVO INMOBILIARIO” PGC2018-095992-B-I00. Ministerio de Ciencia e Innovación. 